\title{
Oceanographic conditions off Coastal South America in Relation to the Distribution Of BURMeister's PORPoise, Phocoena SPINIPINNIS
}

\author{
Daniza Molina-Schiller ${ }^{1}$, Sergio A. Rosales ${ }^{2}$ and Thales R. O. De Freitas ${ }^{1,3}$
}

\begin{abstract}
Aвstract: Historical data (1965-2000) of temperature, salinity, and dissolved oxygen (0 and 50m) were analyzed to understand the seasonal variability of the oceanographic conditions associated to the distribution of $P$. spinipinnis from Paita, Peru $\left(05^{\circ} 01^{\prime} S\right.$, $\left.81^{\circ} \mathrm{W}\right)$, in the Pacific Ocean, to Santa Catarina, Brazil $\left(28^{\circ} 48^{\prime} \mathrm{S}, 49^{\circ} 12^{\prime} \mathrm{W}\right)$, in the Atlantic. The variability of historical average data was associated with different processes as a function of the geographical position and seasonality. These variations have different expressions along each coast as a function of the circulation system in each ocean. The northern boundary of the distribution of $P$. spinipinnis for the Pacific coast at Paita $\left(5^{\circ} \mathrm{S}\right)$ is coincident with the westward turn of the Humboldt Current, as it is incorporated into the South Equatorial Current. In the Atlantic, the northern boundary for the species seems to be associated with the Atlantic Subtropical Convergence $\left(30-40^{\circ} \mathrm{S}\right)$. The high temperature $\left(>24^{\circ} \mathrm{C}\right)$ and salinities $(>36 \mathrm{psu})$ registered at the surface and at $50 \mathrm{~m}$ between the coast and $20 \mathrm{~nm}$ were coincident with the known northern limit of the distribution of this species on both coasts of South America. We propose the existence of three oceanographic areas within the distributional range of P. spinipinnis: (1) from Paita, Peru to south of Arauco Gulf, Chile, that has the influence of the Humboldt Current, and a developed oxygen minimum zone (OMZ); (2) from south of Arauco Gulf to south of La Plata River, Argentina, which shows the influence of the Cape Horn and Malvinas Currents, respectively, as well as downwelling processes, freshwater contributions from fjords, glaciers and rivers; and (3) from La Plata River to Santa Catarina, Brazil, which is characterized by the influence of the Brazil Current, and the freshwater contributions of the basin of La Plata River and the estuarine system of Patos Lagoon, south Brazil. The presence of the OMZ is possibly a factor in the separation of groups (1) and (2) along in the Chilean coast. In addition, we propose that Burmeister's porpoise presents a continuous distribution throughout this range from Paita, Peru to La Plata River basin, Argentina, being able to reach Uruguayan and Brazilian waters under certain oceanographic conditions (intrusion of colder and less saline waters toward the north associated with the Subtropical Convergence).
\end{abstract}

RESUmen: Datos históricos (1965-2000) de temperatura, salinidad y oxígeno disuelto (0 y 50m) fueron analizados para comprender la variabilidad estacional de las condiciones oceanográficas asociadas a la distribución de $P$. spinipinnis desde Paita, Perú $\left(05^{\circ} 01^{\prime} S\right.$, $\left.81^{\circ} \mathrm{W}\right)$ en el Océano Pacífico, hasta Santa Catarina, Brasil $\left(28^{\circ} 48^{\prime} \mathrm{S}, 49^{\circ} 12^{\prime} \mathrm{W}\right)$. La variabilidad de los datos promedios históricos fue asociada con diferentes procesos como una función de la posición geográfica y estacionalidad. Estas perturbaciones tienen diferentes expresiones en cada costa en función de los sistemas de circulación en cada océano. El limite norte de la distribución de P. spinipinnis en la costa Pacifico en Paita $\left(5^{\circ} \mathrm{S}\right)$, es coincidente con la zona donde la Corriente de Humboldt gira al oeste y se incorpora a la Corriente Ecuatorial. En la costa Atlántica, el limite norte para esta especie parece estar asociada a la Convergencia Subtropical del Atlántico $\left(30-40^{\circ} \mathrm{S}\right)$. Altas temperaturas $\left(>24^{\circ} \mathrm{C}\right)$ y salinidades $(>36 \mathrm{psu})$ registradas en superficie y $50 \mathrm{~m}$ de profundidad entre la costa y 20nm fueron coincidentes con el limite norte conocido de la distribución de esta especie en ambas costas de Sudamérica. Nosotros proponemos tres áreas oceanográficas asociadas con la distribución de P. spinipinnis: (1) desde Paita al sur del Golfo de Arauco, Chile, que tiene la influencia de la Corriente de Humboldt y la zona de mínimo oxígeno (ZMO); (2) desde el sur del Golfo de Arauco hasta el Río de La Plata, Argentina, la cual muestra la influencia de las Corrientes del Cabo de Hornos y Malvinas respectivamente y procesos de hundimiento, contribuciones de agua dulce desde los fiordos, glaciares y ríos; y (3) desde el Río de La Plata hasta Santa Catarina, Brasil, la cual esta caracterizada por la influencia de la Corriente de Brasil y los aportes de agua dulce desde la cuenca del Río de La Plata y del sistema estuario de la Lagoa dos Patos, en el sur de Brasil. Probablemente, la presencia de la ZMO es un factor importante en la separación de los grupos (1) y (2) a lo largo de la costa chilena. Además, proponemos que la marsopa espinosa presenta una distribución continua a lo largo de su rango desde Paita, Perú hasta la bacía del Rio de la Plata, Argentina, siendo capaz de alcanzar aguas uruguayas y brasileras bajo ciertas condiciones oceanográficas (entrada de aguas frías y menos salinas hacia el norte asociada a la Convergencia Subtropical).

KeYwords: Phocoena spinipinnis, Burmeister's porpoise, distribution, oceanographic condition, Atlantic Ocean, Pacific Ocean.

\section{Introduction}

The distributions and movements of marine mammals are clearly influenced by their oceanic environment. As indicated by Hastie et al. (2005), although such relationships are inherently dynamic, distributions have been related to a range of environmental determinants, including sea surface temperature (e.g. Selzer and Payne, 1988; Forney, 2000; Baumgartner et al., 2001; Benson et al., 2002; Hamazaki, 2002; Piatkowski et al., 2002; Littaye et al., 2004; Jonhston et al., 2005; Tynan et al., 2005), salinity (e.g. Selzer and Payne, 1988; Forney, 2000; Tynan et al., 2005), and water depth (e.g. Ross et al., 1987; Gowans and Whitehead, 1995; Baumgartner, 1997; Davis et al., 1998; Carretta et al., 2001; Benson et al., 2002; Trukhin, 2003; Tynan et al., 2005). However, the importance of these determinants appears to vary between regions and species, a feature that highlights

\footnotetext{
${ }^{1}$ Universidade Federal do Rio Grande do Sul (UFRGS), PPG em Ecologia. Av. Bento Gonçalves, 9500, Cx. Postal 15007, Porto Alegre, RS 91540-000 Brazil. E-mail: daniza@marinemammals.cl.

${ }^{2}$ Centro de Estudios Pesqueros, Universidad Austral de Chile-Chile. E-mail: sergio.rosales@vtr.net

${ }^{3}$ Universidade Federal do Rio Grande do Sul, Depto. Genética. Av. Bento Gonçalves, 9500, Cx. Postal 15053, Porto Alegre, RS $91501-970$ Brazil. E-mail: thales.freitas@ufrgs.br.
} 
the need to focus studies on the role of oceanography in dolphin habitat selection on a regional basis. In addition, the distribution, abundance and foraging success of top trophic level predators in marine systems, such as sharks, seabirds, pinnipeds, and cetaceans, are determined by large-scale oceanographic patterns and their effect on prey distribution and abundance (Smith et al., 1986; Ainley et al., 1995a, b; Kenney et al., 1995; Pyle et al., 1996; Tynan, 1997; Sydeman and Allen, 1999; Forney, 2000; Benson et al., 2002). In marine systems, heterogeneity of productivy is the result of complex interactions of wind, currents, and land masses (Johnston et al., 2005).

Burmeister's porpoise, Phocoena spinipinnis (Burmeister, $1865)$ is an endemic species of coastal waters of South America, from Santa Catarina, southern Brazil (28 $48^{\prime} \mathrm{S}$, $\left.49^{\circ} 12^{\prime} \mathrm{W}\right)$ to Paita Bay, northern Peru $\left(05^{\circ} 01^{\prime} \mathrm{S}, 81^{\circ} \mathrm{W}\right)$ (Brownell and Praderi, 1982; Simões-Lopez and Ximenez, 1989; Jefferson et al., 1993). However, it is unclear whether or not this species is present continuously throughout this range (Klinowska, 1991; Jefferson et al., 1993; Goodall et al., 1995a;Reeves et al., 2003). This species has been assumed to have a coastal distribution, preferring shallow waters, and indeed most of the sightings have been nearshore (Goodall et al., 1995b). In general, few sightings and movements of $P$. spinipinnis have been reported (e.g. Aguayo, 1975; Donoso-Barros, 1975; Würsig et al., 1977; Guerra et al., 1987; Reyes and Oporto, 1994; Van Waerebeek et al., 2002, Heinrich et al., 20044).

Burmeister's porpoise is associated with a broad range of water temperatures. At the southern limit of its distribution near Cape Horn and Tierra del Fuego, water temperatures range from $3^{\circ} \mathrm{C}$ in June (austral winter) to about $9^{\circ} \mathrm{C}$ in the summer months (Brownell and Praderi, 1982). In the north, the species appears to be associated with temperate waters in the two major northward flowing currents off South America, the Humboldt and the Malvinas Currents (Brownell and Clapham, 1999).

The Humboldt and Cape Horn Currents are the most important currents in the Southeast Pacific, and the distribution of $P$. spinipinnis in this region is associated with both currents. These currents are born by the bifurcation of West Wind Drift or Antarctic Circumpolar Current center at $45^{\circ} \mathrm{S}$. The Humboldt Current has a northward direction from central Chile $\left(40^{\circ} \mathrm{S}\right)$ to northern Peru, where it is incorporated into the South Equatorial Current near to $5^{\circ} \mathrm{S}$ at Paita, Peru (Bakun et al., 1999). The Cape Horn Current has a southward direction, and passes around the continent through the Drake Passage, influencing both east and west coasts of South America (Pickard, 1973).
On the Atlantic coast, the distribution of Burmeister's porpoise is associated with the Brazil and the Malvinas Currents. The Brazil Current originates where the westward flowing trans-Atlantic South Equatorial Current bifurcates into two currents, the North Brazil and the Brazil Currents, with the latter branch having a southward direction (Peterson and Stramma, 1990; Stramma et al., 1990). The Malvinas Current is a branch of the Circumpolar Current and flows northward along the continental shelf of Argentina until it reaches the Brazil Current offshore La Plata River (Legeckis and Gordon, 1982; Garzoli, 1993; Vivier and Provost, 1999). Both currents converge generating the Atlantic Subtropical Convergence or Brazil-Malvinas confluence, which lies between $33-38^{\circ} \mathrm{S}$ along the continental margins of Brazil, Uruguay, and Argentina, and it is considered a major transitional oceanic domain in the Southwest Atlantic (Figure 1) (Olson et al., 1988; Podesta et al., 1991).

The habitat where P. spinipinnis is known to occur shows sectors favorable to upwelling processes, as in the case of the Humboldt Current, which presents several centers of coastal upwelling (Strub et al., 1998; Tarazona and Arntz, 2001). In the case of the Brazil Current, the upwelling is associated with the cyclonic meanders in the region of the Southeast Brazil Bight or Santos Bight (24-265) (Campos et al., 2000). Another difference between the Pacific and Atlantic Oceans is the presence of oxygen minimum zones (OMZs). The OMZs are present along the Pacific coast, at midwater depth in the open ocean where dissolved oxygen concentration falls below $0.5 \mathrm{ml} \mathrm{l}^{-1}$ (Kamykowski and Zentara, 1990; Levin et al., 1991).

To date, few studies have been conducted to determine the effect of oceanographic features and environment variables on the distribution and movements of $P$. spinipinnis (e.g. Würsig et al., 1977; Simões-Lopes and Ximenez, 1993). However, to understand the movements of $P$. spinipinnis it is first necessary to know its distribution at regional scales and mesoscales (10s to $100 \mathrm{~s}$ of $\mathrm{km})$, and later to fine scales (1 to $10 \mathrm{~km}$ ).

The purpose of the present study is to examine the wide distribution of $P$. spinipinnis at regional and temporal mesoscales in relation to oceanographic conditions. Specifically, to explore why Burmeister's porpoise is present in the Pacific and Atlantic Oceans, we hypothesize that the distribution of $P$. spinipinnis, from Santa Catarina, southern Brazil $\left(28^{\circ} 48^{\prime} \mathrm{S}, 49^{\circ} 12^{\prime} \mathrm{W}\right)$ to Paita Bay, northern Peru $\left(05^{\circ} 01^{\prime} \mathrm{S}, 81^{\circ} \mathrm{W}\right)$ is associated with oceanographic conditions (e.g., temperature, salinity, and dissolved oxygen) and circulation systems (e.g. currents, upwelling and donwelling process), because these variables are directly related with seasonal productivity, and with prey distribution and abundance.

\footnotetext{
${ }^{4}$ Heinrich, S., Hammond, P., Christie, C. and Fuentes, M. (2004) Localized distribution and habitat use of Burmeister's porpoises (Phocoena spinipinnis) in the Chiloé Archipiélago, Southern Chile. Pages 164-165 in Abstracts, $11^{\circ}$ Reunión de Trabajo de Especialistas en Mamíferos Acuáticos de América del Sur y $5^{\text {to }}$ Congreso de la Sociedad Latino Americana de Especialistas en Mamíferos Marinos, 11-17 September, Quito, Ecuador.
} 


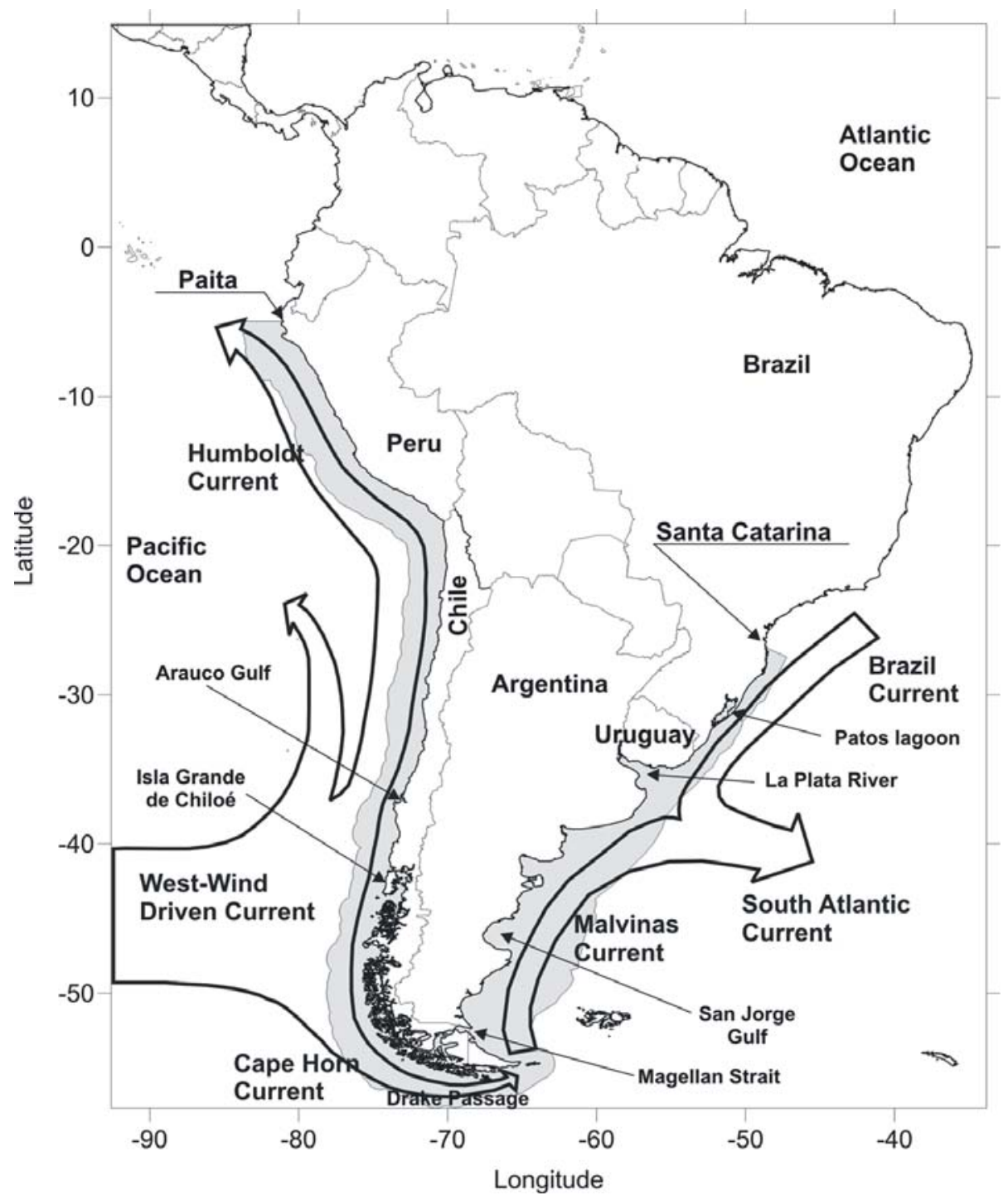

Figure 1. Study area from Paita, Peru $\left(5^{\circ} 01^{\prime} \mathrm{S}\right)$ in the Pacific to Santa Catarina, Brazil $\left(28^{\circ} 48^{\prime} \mathrm{S}\right)$ in the Atlantic off South America and schematic diagram of the main currents.

\section{Material and Methods}

\section{Study area}

The study area corresponds to the known distribution of P. spinipinnis, from Paita, Peru ( $\left.5^{\circ} 01^{\prime} S\right)$ in the Pacific coast to Santa Catarina, Brazil $\left(28^{\circ} 48^{\prime} \mathrm{S}\right)$ in the Atlantic coast of South America. Temperature $\left({ }^{\circ} \mathrm{C}\right)$, salinity (psu) and dissolved oxygen $\left(\mathrm{ml} \mathrm{l}^{-1}\right)$ data at surface and $50 \mathrm{~m}$ of depth, and between the coast and 20 nautical miles (nm) for the Atlantic and Pacific coast were analyzed to understand the seasonal variability of the oceanographic conditions associated with the distribution of $P$. spinipinnis. Although Burmeister's porpoise is considered a coastal species (Brownell and Praderi, 1982, 1984; Goodall et al., 1995a), it has been found up to $50 \mathrm{~km}$ from the coast of north-central Argentina, at a depth of $60 \mathrm{~m}$ (Corcuera, 1991), and at least $20 \mathrm{~km}$ from the coast of Valdivia, Chile (Oporto and Brieva, 1994). Considering these antecedents, we used the 20-nm offshore boundary, because we analyzed the oceanographic conditions associated with the distribution of Burmeister's porpoise at large- and mesoscale and not at fine-scale. If we had conducted the analyses at fine scale, we would only be describing the local variability and would not be able to explain the broad distribution of this species.

For the spatial analysis we used as oceanic boundary the isobath of $100 \mathrm{~m}$ of depth in the Atlantic Ocean. In the Pacific Ocean, we fixed as oceanic boundary the distance of $20 \mathrm{~nm}$ offshore, because the $100 \mathrm{~m}$ isobath is very close to the coast (Figure 1). The definition of season used follows austral schedule: summer (January-March); fall (April-June); winter (July-September); and spring (October-December). However, only the summer and winter distributions will be discussed in detail, as the 
pattern found for temperature, salinity and dissolved oxygen concentration during the fall and spring corresponded to intermediate conditions between the patterns of summer and winter presented here.

\section{Data sources and processing}

Historical data of temperature, salinity, and dissolved oxygen from 1965 to 2000 were used in the analysis of oceanographic conditions. The data were downloaded from the servers of WOCE (World Ocean Circulation Experiment) and NCEP (National Centers for Environmental Prediction). The program Ocean Data View (Schlitzer, 2004) was used for making the selection of all the stations used in this study, and for transforming all data into the same format. The next step was to export the oceanographic data to Microsoft Access, with the purpose of generating for each variable (temperature, salinity and dissolved oxygen) the historical average every 5 minute of latitude and longitude for each season and depth (surface and 50m), respectively. After that, kriging with linear semi-variogram was used to generate georeferenced images using the program Surfer 8.0 (BOSS International, Madison, WI, USA). Finally, program TNTMips 6.7 Lite (MicroImages, Inc., Lincoln, NE, USA) was used to carry out the spatial analysis of the unsupervised classification methods of selfclassification (cluster) using the images of temperature, salinity and dissolved oxygen for each depth and season. This method is based on neuronal networking computing techniques, and was designed to recognize natural groups of spectral patterns in a sample of the input data and to produce a consistent class identification in response to input of similar patterns during classification of the entire images (Microimages, 2001). Finally, an image was generated with the three parameters according to depth and season, respectively.

\section{Results}

\section{General conditions}

A total of 104424 oceanographic stations were selected to carry out the analysis of the historical average conditions. The number of oceanographic stations for the Pacific and Atlantic were different. About 61\% (64358) of the oceanographic stations corresponded to the Pacific. However, the numbers of stations for each season were similar, especially in the Pacific. The distribution the all oceanographic station used in this study is shown in Figure 2.

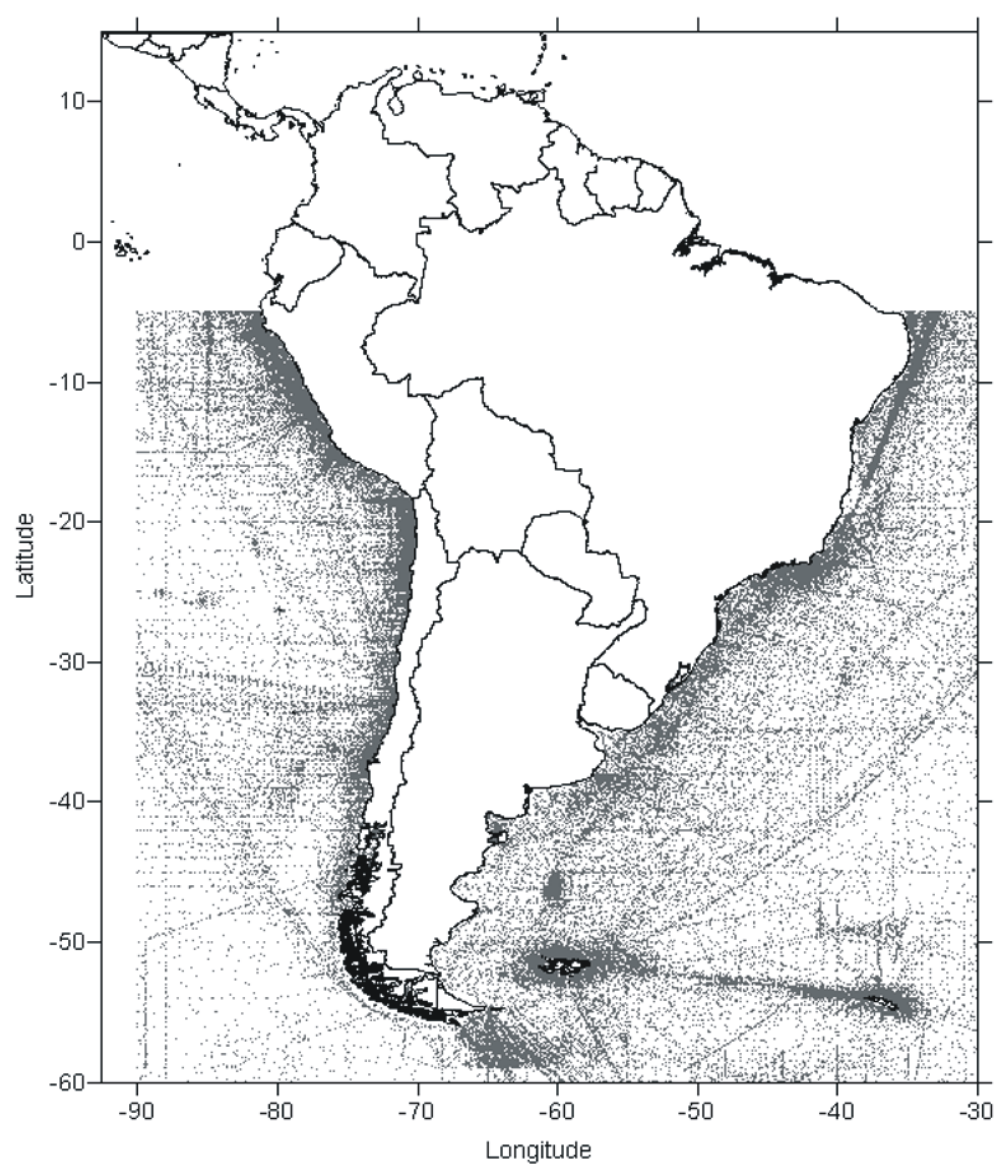

Figure 2. Oceanographic stations used by season from 1965 to 2000 for the Atlantic and Pacific Oceans. 
The average historical data between the coast and 20nm showed great variability in the three parameters analyzed (temperature, salinity and dissolved oxygen) (Table 1). In summer, the maximum temperature observed at surface was $29.1^{\circ} \mathrm{C}$ and $26.6^{\circ} \mathrm{C}$ in the Atlantic and Pacific, respectively (Table 1 ). At $50 \mathrm{~m}$, the maximum temperature in summer was $24^{\circ} \mathrm{C}$ in the Atlantic and $26.3^{\circ} \mathrm{C}$ in the Pacific. The minimum temperatures $\left(2.6-2.8^{\circ} \mathrm{C}\right)$ were recorded at the surface in the Atlantic (in autumn) and Pacific (in summer) (Table 1). At 50m, the minimum temperature was lower in the Pacific (Table 1). Thermal inversions were also observed in the Pacific due to the influence of colder freshwater sources.

The maximum salinities (>36psu) were registered at $50 \mathrm{~m}$ for both the Atlantic and Pacific, respectively. In surface waters, the minimum salinities were observed in austral summer (0.040psu) for the Atlantic and austral spring (0.140psu) for the Pacific (Table 1).

In the Atlantic, the range of dissolved oxygen was from 2.99 to $8.00 \mathrm{ml} \mathrm{l}^{-1}$, while that in the Pacific was from 0.02 to $10.98 \mathrm{ml} \mathrm{l}^{-1}$. The minimum concentrations of dissolved oxygen were recorded in the Pacific, both at the surface and $50 \mathrm{~m}$ of depth (Table 1 ).

\section{Spatial analysis}

\section{- Temperature}

The images of average temperature at the surface and $50 \mathrm{~m}$ of depth in austral summer showed gradual increase in temperature from south to north (Figures 3a,d). In summer, the Pacific coast presented an increment in surface temperature $\left(14^{\circ} \mathrm{C}\right.$ to $\left.22^{\circ} \mathrm{C}\right)$ from $\sim 41^{\circ} \mathrm{S}$ (off Isla Grande de Chiloé, Chile) at $05^{\circ} \mathrm{S}$ (off Paita, Peru). This increase was also observed from the coast to offshore (Figure 3a). The isotherms were semiperpendicular to the coastline, and were associated with the upwelling process. From $41^{\circ} \mathrm{S}$ to the Drake Passage the isotherms were perpendicular to the coast and the surface temperature decreased from $14^{\circ} \mathrm{C}$ to \# $6^{\circ} \mathrm{C}$ (Figure 3a). In the Atlantic, the surface temperature in summer was similar to that of the Pacific. At $46^{\circ} \mathrm{S}$, the isotherms change the orientation from semiperpendicular to parallel to the coast, but in the Pacific the temperature increased toward the coast (Figure 3a). In the austral winter, the minimum surface temperature was similar $\left(6^{\circ} \mathrm{C}\right)$ in both oceans. However, differences were observed in the maximum surface temperature in the Pacific and Atlantic coasts. The isotherm of $14^{\circ} \mathrm{C}$ in the Atlantic coast was missing, while that in the Pacific was found at $28^{\circ} \mathrm{S}$. In the Pacific between $5^{\circ} \mathrm{S}$ and $10^{\circ} \mathrm{S}$, an intrusion of water warmer than $18^{\circ} \mathrm{C}$ was observed from offshore toward the coast. In the Atlantic, the isotherms were perpendicular to the coast, and associated with discharges of rivers, such as Río de la Plata (Figure 3c).

The image of temperature at $50 \mathrm{~m}$ of depth in summer and winter showed that in the Pacific the isotherms tend to be perpendicular to the coast from the Drake Passage to near $29^{\circ} \mathrm{S}$, with temperatures $>5^{\circ} \mathrm{C}$ and $14^{\circ} \mathrm{C}$, respectively. However, lower temperatures were observed at the coast from $29^{\circ} \mathrm{S}$ northwards. In the Atlantic, from $50^{\circ} \mathrm{S}$ to the north, the isotherms presented a tendency to be parallel to the coast, and the

Table 1. Minimum and maximum values of temperature, salinity and dissolved oxygen from Paita, Peru ( $\left.5^{\circ} 01^{\prime} S\right)$ in the Pacific to Santa Catarina, Brazil $\left(28^{\circ} 48^{\prime} S\right)$ in the Atlantic off South America between 1965 to 2000, by depth (surface and 50m) and season.

\begin{tabular}{|c|c|c|c|c|c|c|c|c|}
\hline \multirow[t]{2}{*}{ OCEAN } & \multirow{2}{*}{$\begin{array}{c}\text { DEPTH } \\
(\mathrm{m})\end{array}$} & \multirow[t]{2}{*}{ SEASON } & \multicolumn{2}{|c|}{$\begin{array}{c}\text { TEMPERATURE } \\
\left({ }^{\circ} \mathrm{C}\right) \\
\end{array}$} & \multicolumn{2}{|c|}{$\begin{array}{c}\text { SALINITY } \\
(\mathrm{psu})\end{array}$} & \multicolumn{2}{|c|}{$\begin{array}{c}\text { DISSOLVED OXYGEN } \\
\left(\mathrm{ml} \mathrm{l}^{-1}\right) \\
\end{array}$} \\
\hline & & & $\min$ & $\max$ & $\min$ & $\max$ & & \\
\hline \multirow{8}{*}{ Atlantic } & \multirow{4}{*}{0} & Summer & 19.3 & 29.1 & 0.040 & 35.800 & 3.80 & 8.00 \\
\hline & & Fall & 2.6 & 25.1 & 0.440 & 35.651 & 2.99 & 8.00 \\
\hline & & Winter & 11.5 & 21.1 & 0.070 & 35.519 & 4.43 & 8.00 \\
\hline & & Spring & 13.2 & 23.8 & 0.430 & 35.817 & 3.09 & 8.00 \\
\hline & \multirow{4}{*}{50} & Summer & 15.8 & 24.0 & 34.976 & 35.855 & 2.73 & 5.52 \\
\hline & & Fall & 2.6 & 23.3 & 33.785 & 36.272 & 2.83 & 7.45 \\
\hline & & Winter & 16.3 & 19.5 & 31.932 & 35.845 & 3.69 & 6.03 \\
\hline & & Spring & 14.5 & 19.4 & 35.364 & 35.960 & 3.44 & 5.42 \\
\hline \multirow{8}{*}{ Pacific } & \multirow{4}{*}{0} & Summer & 2.8 & 26.6 & 1.289 & 35.668 & 0.08 & 10.98 \\
\hline & & Fall & 4.8 & 23.3 & 9.999 & 35.796 & 0.87 & 9.89 \\
\hline & & Winter & 4.7 & 21.5 & 12.496 & 35.486 & 1.44 & 9.20 \\
\hline & & Spring & 5.2 & 24.2 & 0.140 & 35.429 & 0.15 & 9.42 \\
\hline & \multirow{4}{*}{50} & Summer & 5.9 & 26.3 & 5.000 & 36.008 & 0.03 & 7.60 \\
\hline & & Fall & 8.0 & 21.2 & 30.259 & 35.190 & 0.02 & 6.69 \\
\hline & & Winter & 5.2 & 19.2 & 27.440 & 35.540 & 0.02 & 8.00 \\
\hline & & Spring & 6.0 & 23.6 & 22.024 & 35.500 & 0.02 & 7.01 \\
\hline
\end{tabular}


a)

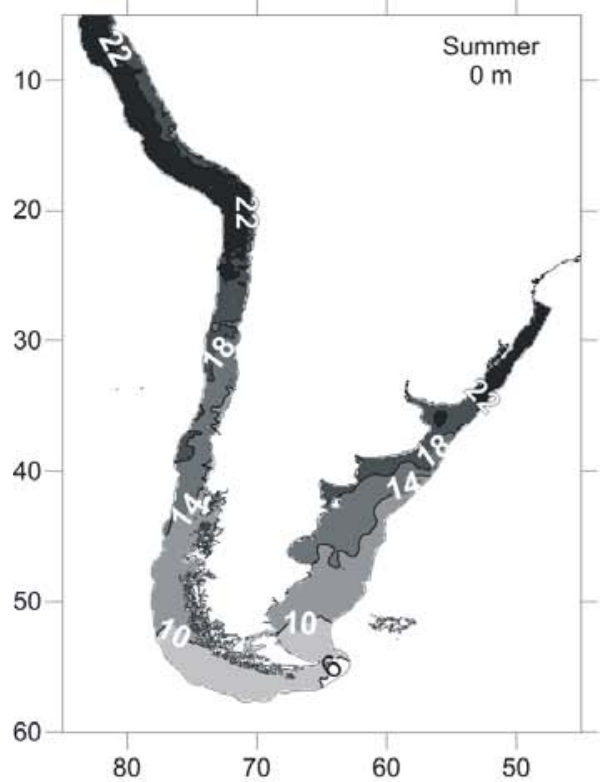

c)

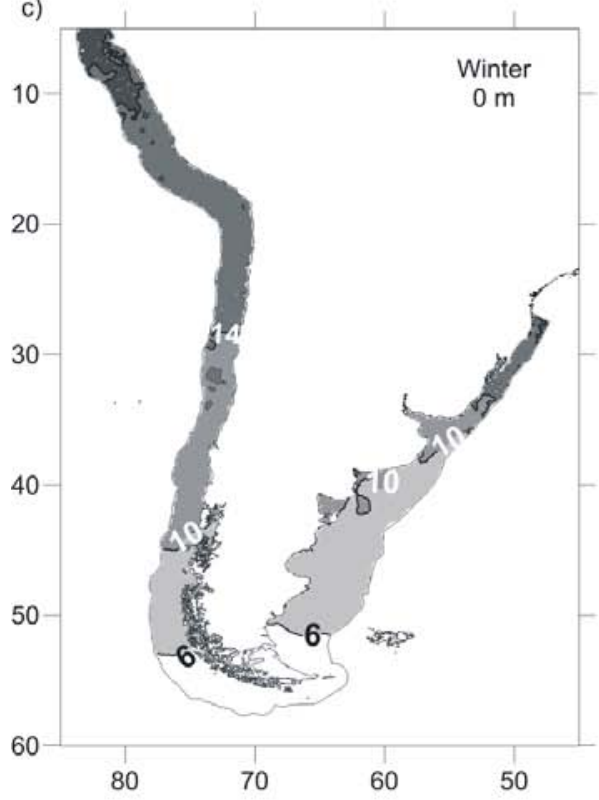

b)

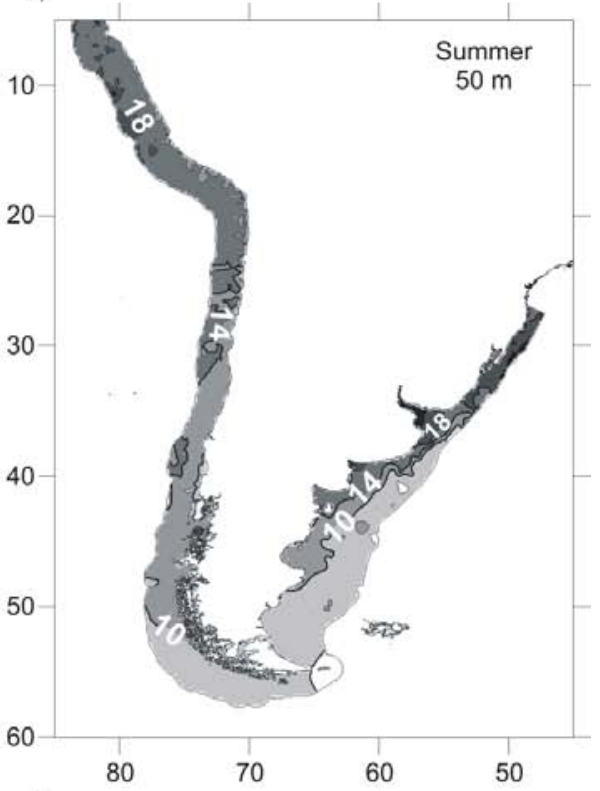

d)

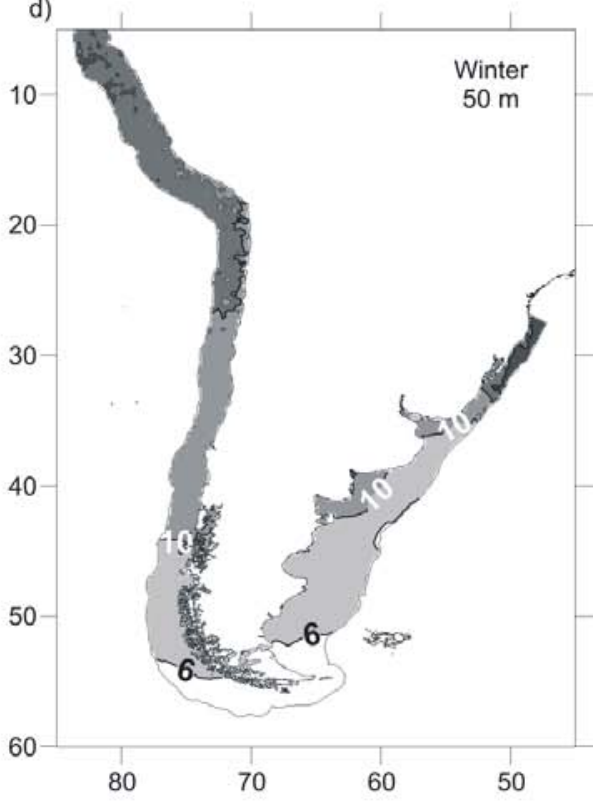

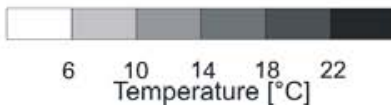

Figure 3. Historical average temperature: a) summer $0 \mathrm{~m}, \mathrm{~b}$ ) summer $50 \mathrm{~m}, \mathrm{c}$ ) winter $0 \mathrm{~m}$ and d) winter $50 \mathrm{~m}$.

temperature was greater than $10^{\circ} \mathrm{C}$ (Figures $\left.3 \mathrm{~b}, \mathrm{~d}\right)$.

\section{- Salinity}

In the Atlantic and Pacific, both at the surface and 50m, salinity increases from south to north. Higher salinities (\$35psu) were observed near the northern boundary of the study area off the Peruvian and Brazilian coasts (Figures $4 a, d$ ). In summer, the salinity off the Argentine coast at the surface and $50 \mathrm{~m}$ was between $33-34 \mathrm{psu}$. This was similar to the Chilean coast south of $33^{\circ} \mathrm{S}$
(Figures $4 a, b)$. However, in the Pacific the salinity increases gradually at the surface ( $>35 \mathrm{psu}$ ) and offshore north of $26^{\circ} \mathrm{S}$, but in winter this limit moves further northwards (Figures 4c,d). The minimum salinity observed reflects the contributions of freshwater from fjords, glaciers, and rivers, mainly in the Atlantic, where there is a great contribution of freshwater from the basin of the La Plata River. In the Pacific, lower surface salinities were observed in the zone of channels and fjords, due to the contributions of freshwater from precipitation, draining, rivers, and glacier 
a)
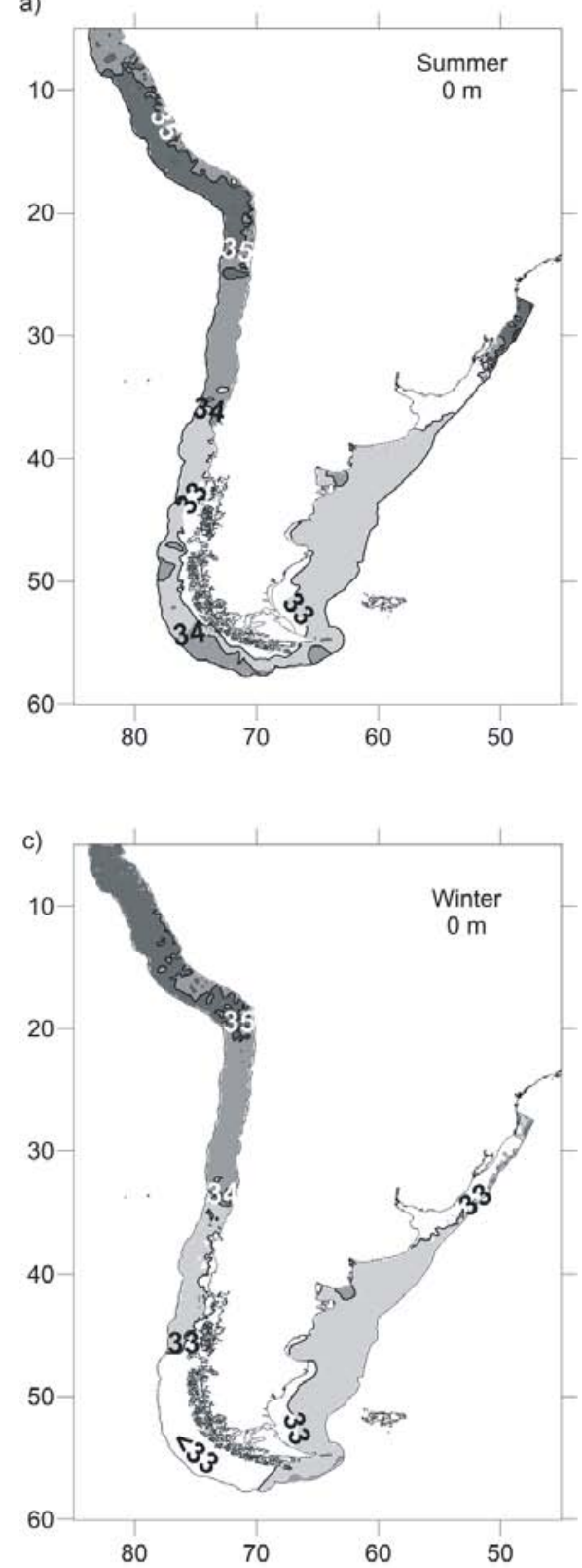

b)

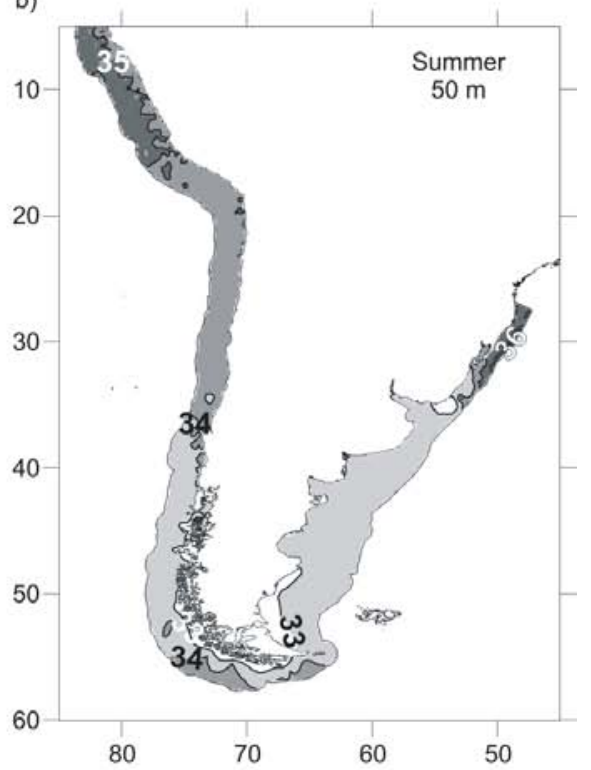

d)

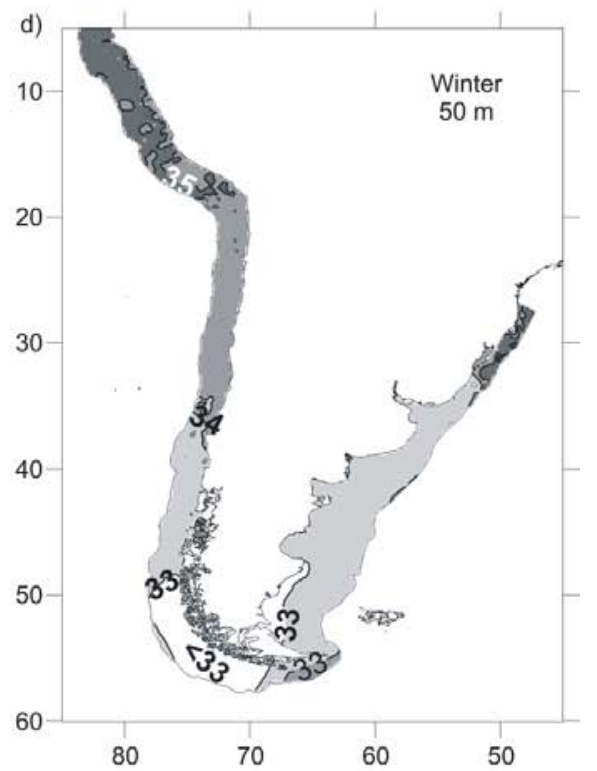

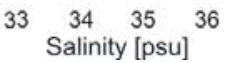

Figure 4. Historical average salinity: a) summer 0m, b) summer 50m, c) winter 0m and d) winter 50m.

melting.

- Dissolved oxygen

The dissolved oxygen concentration in the Atlantic and Pacific increases from the north southwards, both at the surface and at 50m (Figures 5a,d). However, there is a decrease in dissolved oxygen from surface to depth in the Pacific. The lower concentration of dissolved oxygen was associated with the influence of the OMZs, and in the coastal zone of the Peruvian coast, the upper limit of OMZs was closer to the surface.

The Patagonia area presented the greater dissolved oxygen concentrations $\left(>6 \mathrm{ml} \mathrm{l}^{-1}\right)$ (Figures $\left.5 \mathrm{a}, \mathrm{d}\right)$. These waters are mixed during the winter by the action of winds, which increase the thickness of the Ekman Layer. On the continental shelf of Argentina, the Malvinas Current transports more oxygenated water to the north (Figures 5c,d). Off the Brazilian and Uruguayan coasts the water is less oxygenated, between $4-6 \mathrm{ml} \mathrm{l}^{-1}$, with a minimum near to $2 \mathrm{ml} \mathrm{l}^{-1}$ in the area of Patos Lagoon, 
a)

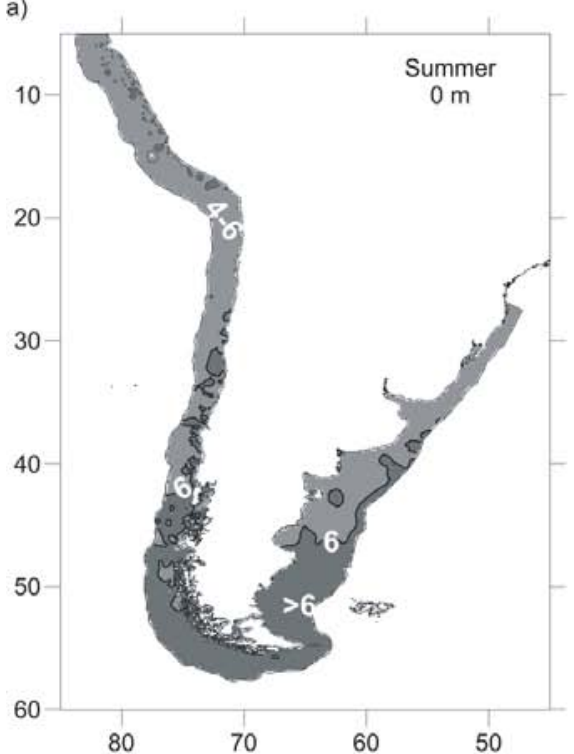

c)

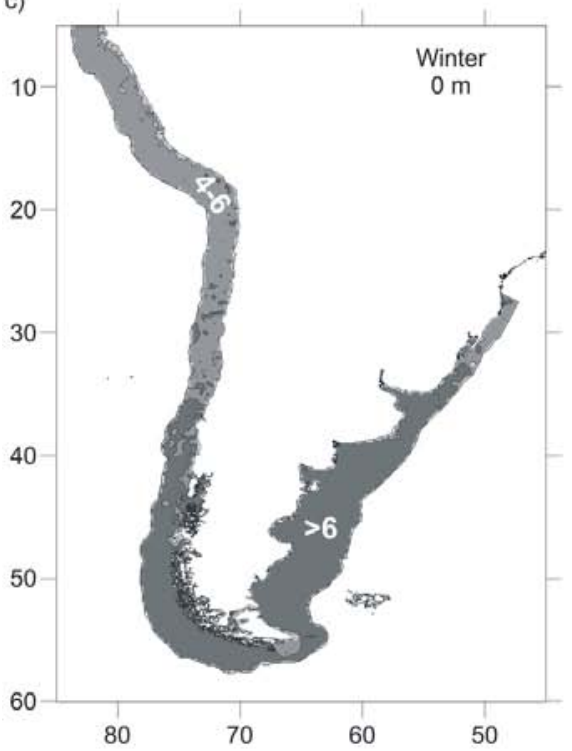

b)

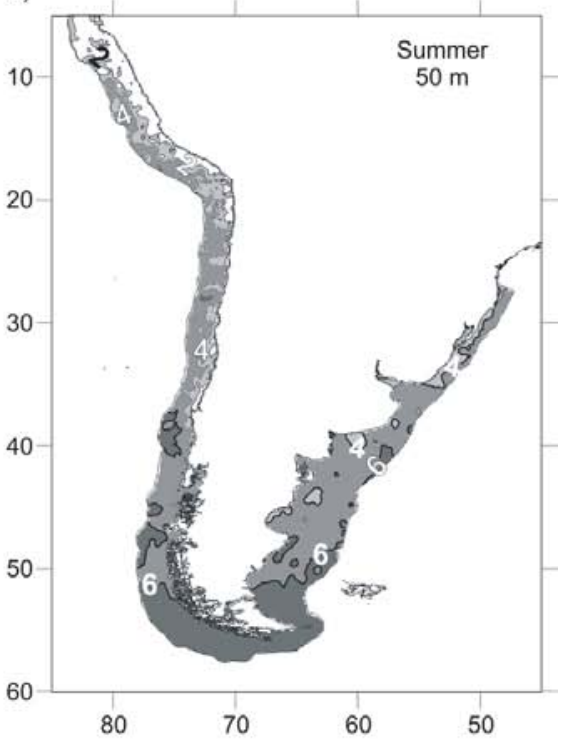

d)

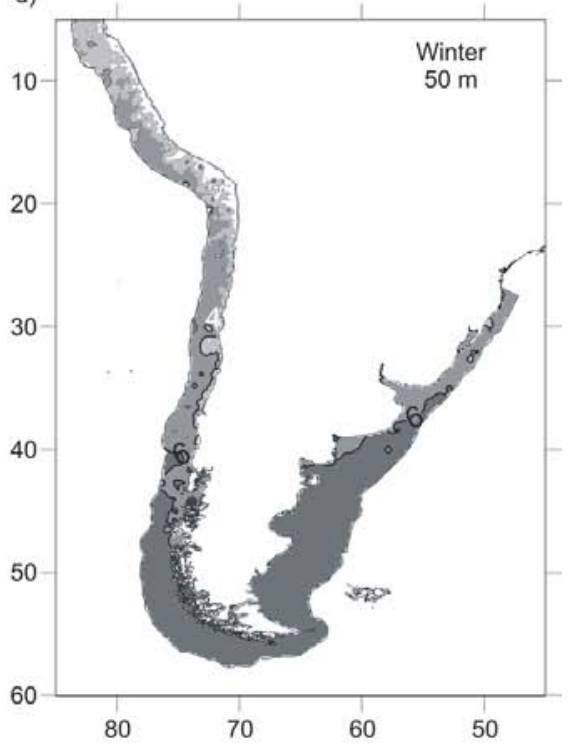

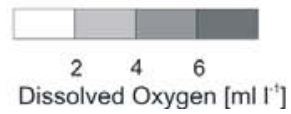

Figure 5. Historical average dissolved oxygen: a) summer 0m, b) summer 50m, c) winter 0m and d) winter 50m.

south Brazil $\left(32^{\circ} \mathrm{S} ; 49^{\circ} \mathrm{W}\right)$ (Figure $\left.5 \mathrm{~b}\right)$. In the Pacific, north of $40^{\circ} \mathrm{S}$ the dissolved oxygen concentration was between $4-6 \mathrm{ml} \mathrm{l}^{-1}$ (Figures 5a,c), and near the coast at 50m upwelling water from the OMZs, with values $<0.5 \mathrm{ml} \mathrm{l}^{-1}$ was observed (Figures 5b,d).

\section{- Self-classification}

The self-classification method shows that the image obtained for the surface generated three different groups
(Figure 6). The first group was associated with more temperate and saline waters, and it was present in fall, winter and spring from northern Peru $\left(5^{\circ} \mathrm{S}\right)$ to $\sim 40^{\circ} \mathrm{S}$ in the Pacific (Figures $6 b, c, d$ ). In summer, this group presented a minimum distribution from $5^{\circ}$ to $33^{\circ} \mathrm{S}$ (Figure 6a). Off the Atlantic coast, this group showed a minimum distribution in winter from $38^{\circ}$ to $28^{\circ} \mathrm{S}$ (Figure 6c), and with fluctuations along the coast from La Plata River to the north, especially in summer and fall.

The second group includes the austral waters, and their 
a)

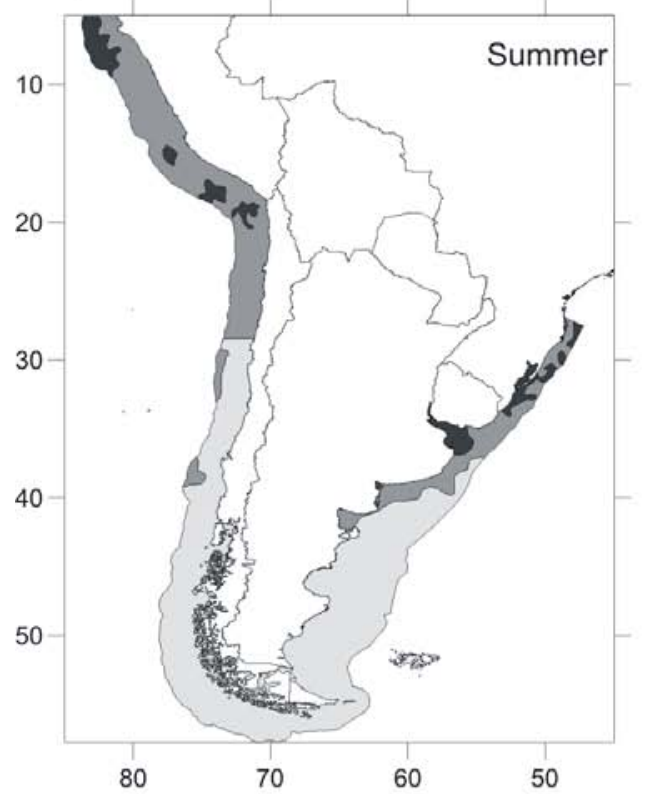

c)

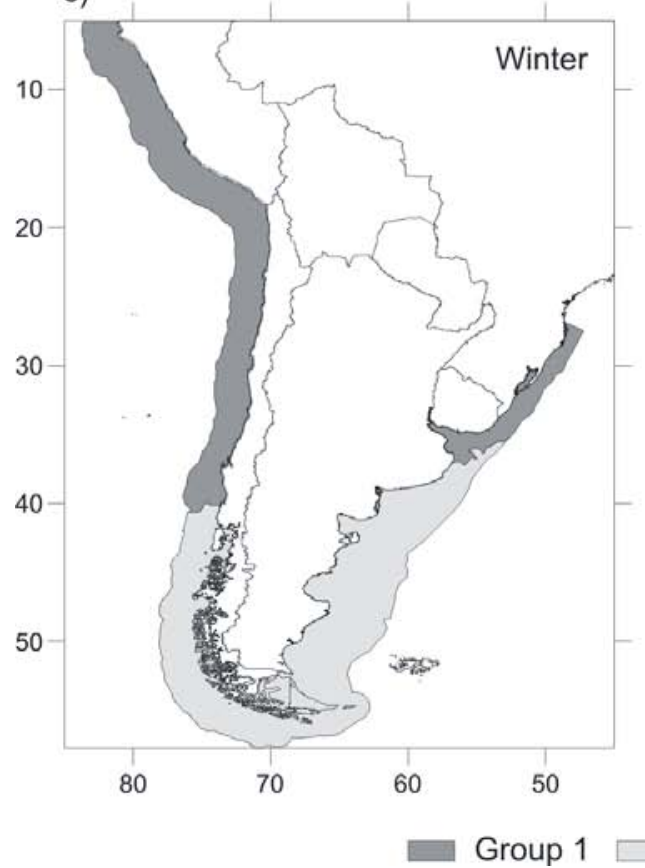

b)

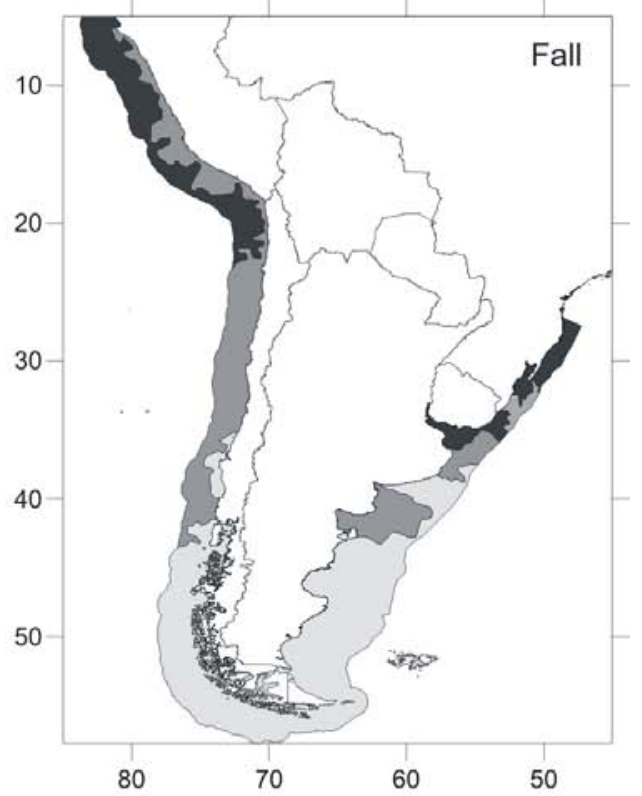

d)

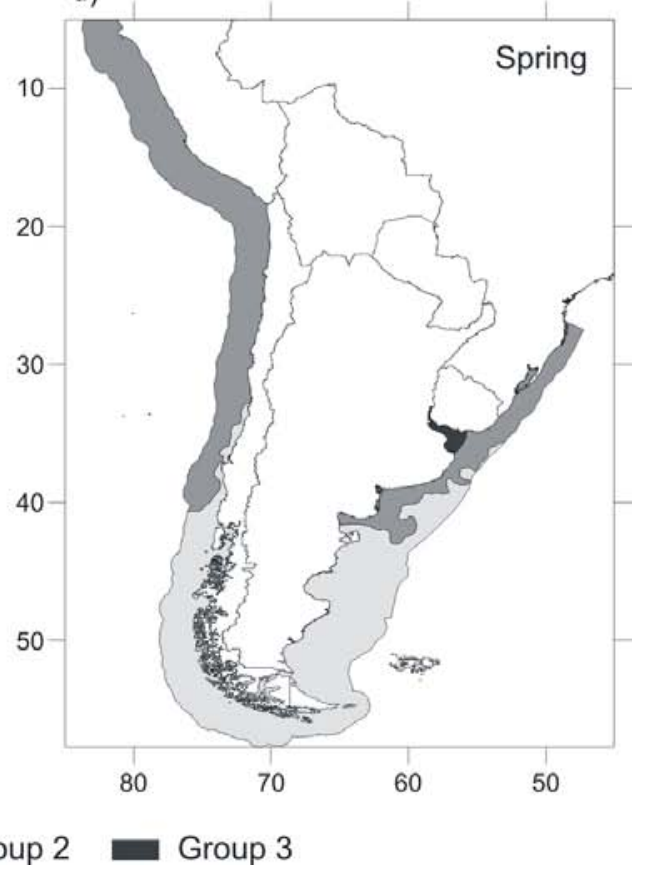

Figure 6. Groups generated for each season at the surface by self-classification methods.

associated seasonal fluctuations. In the Atlantic, this group was associated with the Malvinas Current in all four seasons, and in the Pacific it was associated with the Cape Horn Current in fall, winter, and spring (Figures $6 b, c, d$ ). In summer, this group expands its distribution to the north $\left(\sim 40^{\circ} \mathrm{S}\right.$ to $\left.33^{\circ} \mathrm{S}\right)$, where there is the influence of the Humboldt Current and the upwelling waters (Figure 6a). The third group in the Pacific coast was associated with an intrusion of oceanic waters from offshore toward the Peruvian coast. In the Atlantic this group has a contribution of freshwater from the riverine basins discharging along the Uruguayan and Brazilian coasts (e.g.. La Plata River, Patos Lagoon) as well as runoff (Figures 6a,b). The first and the second groups were present year-round, but the third group was absent in winter (Figure 6c).

At 50m, the self-classification method showed the same groups observed at the surface (Figures 7a,b,c). However, in spring a fourth group was created in the austral zone from the Magellan Strait in the Pacific to south of San 
Jorge Gulf, off Argentina, in the Atlantic (Figure 7d).

Based on the results of this study, we propose three oceanographic areas relevant to the distribution of $P$. spinipinnis:

(1) The first area, from Paita, northern Peru $\left(5^{\circ} \mathrm{S}\right)$, to south of the Arauco Gulf, Chile $\left(-39^{\circ} \mathrm{S}\right)$, has the influence of the Humboldt Current, which involves upwelling that carries water rich in nutrients, colder, more saline and low in oxygen, and also contains an oxygen minimum zone (Figure 8);

a)

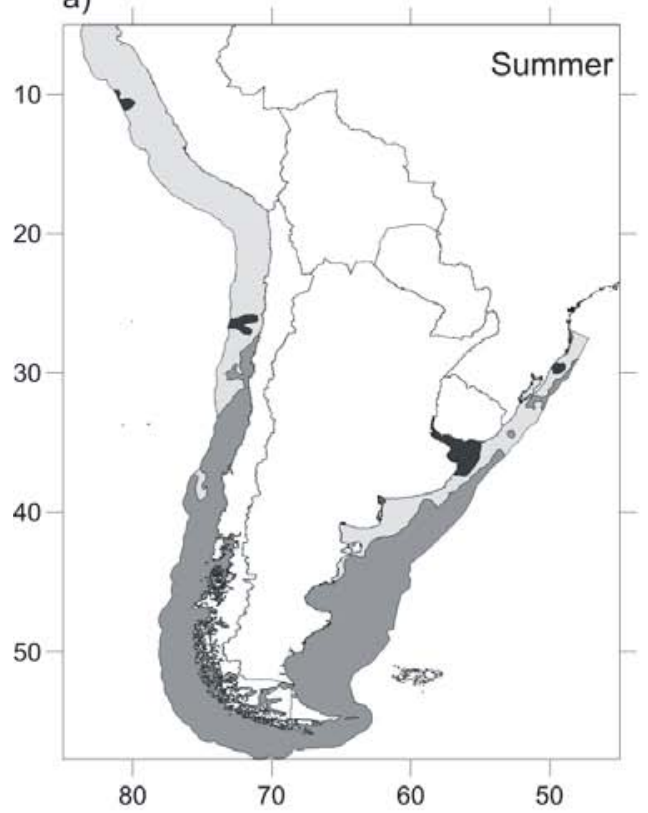

c)

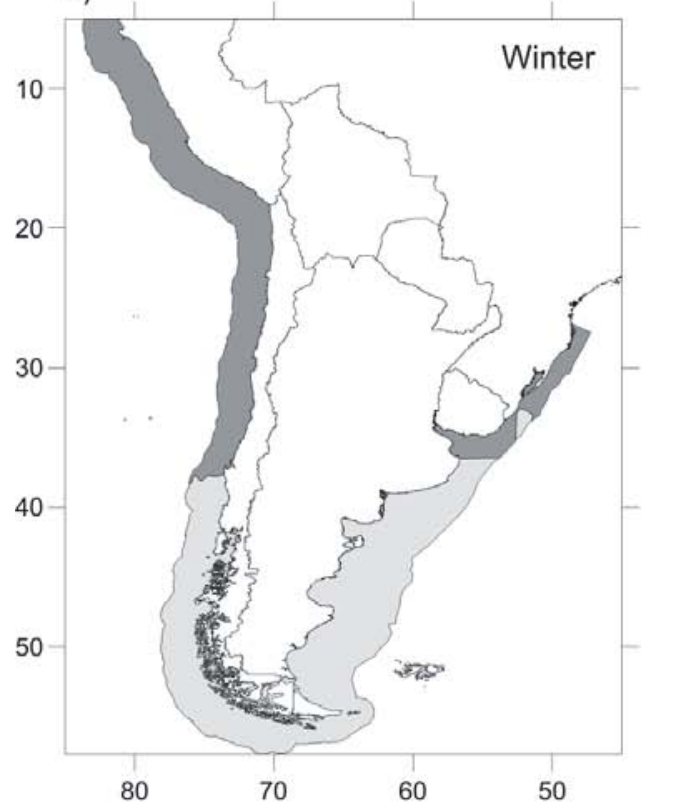

(2) The second area, from south of Arauco Gulf to south of La Plata River $\left(\sim 38^{\circ} \mathrm{S}\right)$ shows the influence of Cape Horn and Malvinas Currents, and involves downwelling processes, and freshwater contributions from fjords, glaciers and rivers (Figure 8);

(3) The third area, from La Plata River to Santa Catarina, Brazil $\left(28^{\circ} \mathrm{S}\right)$ is characterized by the influence of the Brazil Current, and the freshwater contributions of the basin of La Plata River and the estuarine system of Patos Lagoon (Figure 8).

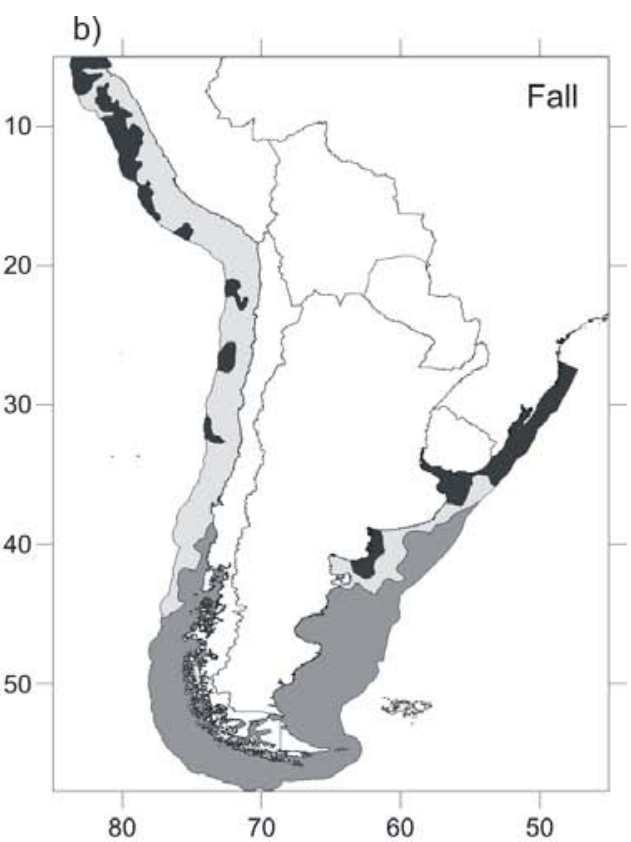

d)

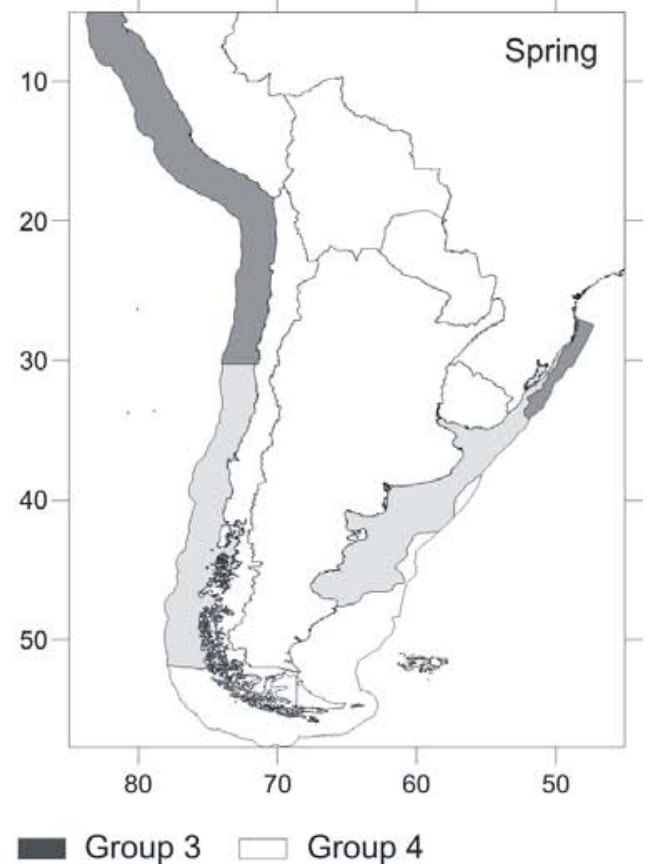

Figure 7. Groups generated for each season at $50 \mathrm{~m}$ by self-classification methods. 


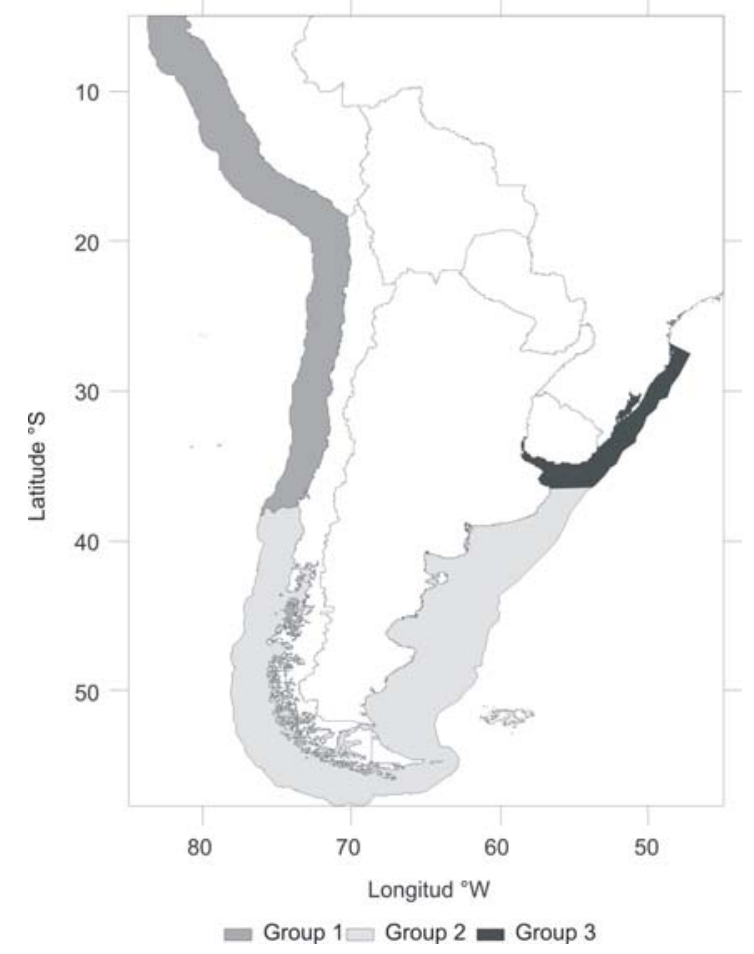

Figure 8. Proposed oceanographic zones associated with the distributions of Phocoena spinipinnis.

\section{Discussion}

The variability of average historical data of temperature, salinity, and dissolved oxygen analyzed in this study is associated with different processes related to the geographical position and the influence of seasonality. This has been described by several authors (e.g. Lima et al., 1996; Piola et al., 2000; Blanco et al., 2001; Rivas and Piola, 2002; Sabatini et al., 2004).

Results from this study clearly show the influences of oceanographic conditions on the distribution of Burmeister's porpoise in both oceans. The characterization of the oceanographic conditions showed that the northern boundary of the distribution of $P$. spinipinnis for the Pacific coast at Paita, Peru $\left(5^{\circ} \mathrm{S}\right)$ is coincident with the westward turn of the Humboldt Current, as it is incorporated into the South Equatorial Current. In the Atlantic, the northern boundary seems associated with the Atlantic Subtropical Convergence (30$40^{\circ} \mathrm{S}$ ), as was originally proposed by Brownell and Clapham (1999) and Goodall et al. (1995a). In addition, the high temperatures $\left(>24^{\circ} \mathrm{C}\right)$ and salinities (>36psu) recorded at the surface and $50 \mathrm{~m}$ between the coast and the $20 \mathrm{~nm}$ boundary were coincident with the known northern limit of the distribution of $P$. spinipinnis on both coasts of South America (Goodall et al., 1995a,b; Reyes and Van Waerebeek, 1995; Brownell and Clapham, 1999). The characterization of the oceanographic conditions from Paita, Peru to Santa Catarina, Brazil showed a clear separation in three major areas. The differences in distribution of $P$. spinipinnis between the different oceanographic areas is based on an assumption of seasonal variations of the parameters examined.

The first oceanographic area, from Paita, northern Peru $\left(5^{\circ} \mathrm{S}\right)$ to south of Arauco Gulf, Chile $\left(\sim 39^{\circ} \mathrm{S}\right)$ is characterized by the presence of the Humboldt Current and an OMZ, with an average temperature between 14$22^{\circ} \mathrm{C}$, salinity between 34-35psu, and dissolved oxygen from values lower than 1 to $6 \mathrm{ml} \mathrm{l}^{-1}$. These characteristics are coincident with the seasonal ranges of surface temperature and salinity observed by Blanco et al. (2001).

The influence of the Humboldt Current System in the first area is very important, because a significant exchange of heat and $\mathrm{CO}_{2}$ takes place between the ocean and the atmosphere due to upwelling of sub-surface, cold, nutrient-rich, $\mathrm{CO}_{2}$-saturated waters. This fertilization of the photic zone increases primary production and the uptake of $\mathrm{CO}_{2}$ (Escribano et al., 2003). The Humboldt Current System with its coastal upwelling ecosystem off Peru and Chile is recognized as a highly productive region, sustaining large fisheries of anchovies and sardines (Alheit and Bernal, 1983; Mann and Lazier, 1991; Walsh, 1991). Burmeister's porpoise occurring in the upwelling system might be particularly vulnerable to local depletion as they inhabit a very rich, but unstable environment (e.g. due to recurring El Niño events). Detailed studies of stomach contents of porpoises from Peru and Chile have shown that their most common prey were primarily anchovy (Eugraulis ringens), hake (Merluccius gayi), and jack mackerel (Trachurus murphyi) (Torres et al, 1992; Reyes and van Waerebeek, 1995).

Although cetaceans are highly mobile predators and their distribution is dynamic, habitat selection often seems to correspond with hydrographic domains associated with bathymetric features (Baumgartner, 1997; Moore et al., 2000), so the assumption of some annual pattern of cetacean distribution and abundance seems warranted. Probably, the presence of the OMZs in the southeastern Pacific Ocean, from the latitude of the Galápagos Islands $\left(\sim 1^{\circ} \mathrm{S}\right)$ to southern Chile $\left(\sim 40^{\circ} \mathrm{S}\right)$ (Gallardo, 1963; Rosenberg et al., 1983; Arntz et al., 1991), is an important factor in the separation of two oceanographic areas observed in this study for the Chilean coast, and its limit seems to be south of the Arauco Gulf $\left(-39^{\circ} \mathrm{S}\right)$ (Gutierrez et al., 2000). According to time series data in northern Chile (1980 to 1997, JGOFS and FONDAP-HUMBOLDT Projects), the oxycline is located at $50 \mathrm{~m}$ of depth at the coast, and at $100 \mathrm{~m}$ of depth in oceanic waters. However, this limit has been detected in shallower waters at $10 \mathrm{~m}$ during strong El Niño, as the event of 1997-1998.

The upper limit of OMZs presents a great vertical intra and interannual variability associated with dynamic processes in the system (Morales et al., 1999). The upper and lower boundaries of OMZs have been characterized as sites of enhanced biological and biogeochemical 
activity (Wisher et al., 1995), including the coupling of nitrification and denitrification processes (Anderson et al., 1982). In addition, OMZs represent an effective barrier of vertical distribution and diversity of plankton, micronekton, and benthic species or assemblages, though some organisms are adapted to these extreme conditions (Wisher et al., 1995).

The second oceanographic area proposed here is from south of the Arauco Gulf, Chile to south of La Plata River, Argentina $\left(\sim 38^{\circ} \mathrm{S}\right)$. This group is characterized by the influence of the Cape Horn and Malvinas Currents, and freshwater contributions (especially from fjords, glaciers and the La Plata River Basin) with temperature values between $6^{\circ}-22^{\circ} \mathrm{C}$, salinity between 33-35psu and dissolved oxygen between $2-6 \mathrm{ml} \mathrm{1}^{-1}$. The maximum record of temperature associated with a Burmeister's porpoise sighting ranged between $17.5^{\circ}$ and $19.5^{\circ} \mathrm{C}$ (summer) in San José Gulf, Argentina (Würsig and Würsig, 1980) and Tierra del Fuego to near Cape Horn, average from $4^{\circ} \mathrm{C}$ (winter) to $9^{\circ} \mathrm{C}$ (summer) (Goodall et al., 1995a).

The low value of salinity recorded in spring off the Pacific coast was associated with the melting of glaciers at that time. The excess of precipitation in the Southeast Pacific and continental runoff from southern Chile reduced the salinity over the shelf of the Atlantic coast to values <33.9psu (Deacon, 1933; Lusquiños and Valdéz, 1971). Several authors observed the remarkable permanent salinity minimum existing off southern Chile (Silva and Neshyba, 1979; Neshyba and Fonseca, 1980; Sievers and Nowlin, 1989; Silva et al., 1997). According to these authors, the main driving forces in this zone are contributions of freshwater from rivers, runoff, rain and glaciers; mixing of freshwater with saline waters; subsurface advection of more saline waters with oceanic origin, and vertical mixing by wind shear.

There are two types of freshwater discharges over the Patagonian shelf, in Argentina.The first is related to drainage of continental rivers along the coast of southern Patagonia, and the second is the inflow of diluted waters from the Magellan Strait (Panella et al., 1991). Although there is only scant information about the magnitude of the influx of the relatively fresher waters from the Magellan Strait, the water mass structure of the Patagonian shelf is strongly influenced by a freshwater 'tongue', which has its salinity minimum in that region and is known as the Patagonian Current (Sabatini et al., 2004). This is similar to what was observed in this study (Figure 4).

In the second oceanographic area we proposed, the salinity minimum (>33psu) at 50m depth in the Atlantic indicates that the contributions of freshwater are concentrated at the surface, and do not reach $50 \mathrm{~m}$, with the exception of the low salinity observed in winter (31.93psu). This can be attributed to a stronger mixing of the water column that would allow the dilution of water at this depth with surface freshwaters. In the Pacific there was a larger contribution of freshwater in the water column, corresponding to that found by Dávila et al. (2002), who determined the large effect of freshwater offshore in fall. With regard to dissolved oxygen, the highest concentrations were found in the southern zone (for both Pacific and Atlantic coasts), and were associated with the turbulent mixing of the water column by the wind action. This mixing is more intense because of the continual passage of frontal systems, especially in the Pacific coast, where the concentrations are larger than in the Atlantic coast at $50 \mathrm{~m}$.

In this area, sightings of Burmeister's porpoise have been made at least $20 \mathrm{~km}$ from coast of Valdivia, Chile, especially in winter when sardines move offshore (Oporto and Brieva, 1984), in mouths of rivers and estuaries (Aguayo, 1975), and appear to be fairly common in bays off the intricate channels of Tierra del Fuego in the southernmost part of the range (Goodall et al., 1990; 1995), and in San José Gulf, Argentina (Würsig and Würsig, 1980). Heinrich et al. (2004) mention that Burmeister's porpoises from Chiloé Archipelago (42$\left.43^{\circ} \mathrm{S}\right)$ seemed to prefer significantly deeper waters (mean depth $=37 \mathrm{~m}$ ) and further from shore (mean distance to shore $=963 \mathrm{~m}$ ).

The third oceanographic area proposed here, from La Plata River to Santa Catarina, Brazil $\left(28^{\circ} \mathrm{S}\right)$, is characterized by the influence of the Brazil Current, and the freshwater contributions of the La Plata River basin and the estuarine system of Patos Lagoon. This is coincident with that observed by Piola et al. (2000), who analyzed historical hydrographic data in the upper layer over the continental shelf off eastern South America and concluded that there is a widespread influence of continental discharge, primarily from La Plata River Basin and locally from Patos Lagoon.

During the austral winter, the low-salinity plume reaches $28^{\circ} \mathrm{S}$, while in summer it is constrained to south of $32^{\circ} \mathrm{S}$. The seasonal variability of the along shore extent of the low-salinity plume, presumably induced by variations in the wind stress, is larger than the changes induced by the variability in river discharge.

The Subtropical Convergence has enormous importance to the geographical distribution of the South American biota. This convergence, which in the summer is located at the latitude of Montevideo (Uruguay), can reach Florianópolis (Brazil) during winter, creating rich fishing areas (CARPAS, 1964). This would explain the occasional presence of $P$. spinipinnis in Brazil, because the three records of Burmeister's porpoise for Brazil were in spring 1986, near the Uruçanga river mouth, Santa Catarina state $\left(28^{\circ} 48^{\prime} \mathrm{S}\right)$ (Simões-Lopez and Ximenez, 1993). The second and third record were on the coast of Rio Grande do Sul, in summer 1986 (3240'S; $52^{\circ} 26 \mathrm{~W}$ ) (Pinedo, 1989), and summer 2000 off Farol Berta $\left(30^{\circ} 23.9^{\prime} \mathrm{S} ; 50^{\circ} 17.2^{\prime} \mathrm{W}\right)$ (Ignacio Moreno, GEMARS, pers. comm.). These records were coincident with the intrusion of colder and less saline waters northwards. According to Silva et al. (1984), in these latitudes, salinities between 33-36psu, and the surface temperature 
tends to be lower near shore $\left(16-22^{\circ} \mathrm{C}\right)$, gradually rising in deeper waters offshore $\left(23-27^{\circ} \mathrm{C}\right)$. In addition, Pimenta (2001) analyzed the variability of the La Plata plume by simulations with a numerical model as a function of wind stress and intensity of river discharge, including the effect of La Niña and El Niño periods and found that the average speed of the plume along the shore was directly related to the intensity of the outflow, and the northward extent of the plume along the shelf varied from $850 \mathrm{~km}$ to $1550 \mathrm{~km}$, for La Niña and El Niño, respectively. Considering these conditions, we propose that the habitat of Burmeister's porpoise in the Atlantic is associated with the Subtropical Convergence. When intrusions of colder and less saline waters occur northwards, P. spinipinnis can move to the north, reaching the latitude of Florianópolis $\left(28^{\circ} 48^{\prime} \mathrm{S} ; 49^{\circ} 12^{\prime} \mathrm{W}\right)$, southern Brazil. Silva et al. (1984) reveal upwelling areas to the north of the Santa Catarina coast, as well as in the region between Santa Marta Cape and Florianópolis.

The movements of cetaceans and other mobile marine predators are driven primarily by physical oceanographic conditions, particularly at lower trophic levels (Angel, 1994; Fiedler et al., 1986; Benson et al., 2002). The feeding ecology of Burmeister's porpoise is not well known, but regional differences in feeding habits are likely.

Considering the existing information on Burmeister's porpoise based on sightings, strandings and incidental captures (Corcuera et al., 1995; Goodall et al., 1995a,b; Reyes and Van Waerebeek, 1995) from Paita, Peru to Santa Catarina, Brazil, and the oceanographic characterization of habitat of $P$. spinipinnis obtained in this study, we propose that Burmeister's porpoise presents a continuous distribution throughout this range from Paita, Peru, to La Plata River Basin, Argentina, being able to reach Uruguayan and Brazilian waters under certain oceanographic conditions (e.g. intrusion of colder and less saline waters toward the north associated to the Subtropical Convergence).

Better information on spatial and temporal variation of the diet and habit use of $P$. spinipinnis, combined with feeding behavior are necessary to improve current models of prey consumption. The results provide useful information use in understanding the ecology of Burmeister's porpoise, and hopefully will help managers address concerns about the potential impacts of anthropogenic activity on this species. The analyses presented in this study may also provide relevant habitat information for a number of other marine mammal species present in the study area.

\section{Conclusions}

Our results support a clear separation of the distribution of Burmeister's porpoise into three large areas: (1) from Paita, northern Peru ( $\left.5^{\circ} \mathrm{S}\right)$, to south of the Arauco Gulf, Chile $\left(-39^{\circ} \mathrm{S}\right)$ with the influence of the Humboldt Current and OMZ; (2) from south of Arauco Gulf to south of La
Plata River, Argentina, $\left(-38^{\circ} \mathrm{S}\right)$ associated with the Cape Horn and Malvinas Currents, as well as freshwater contributions; (3) from La Plata River to Santa Catarina, Brazil $\left(28^{\circ} \mathrm{S}\right)$, with the influence of the Brazil Current, and the contributions of freshwater from La Plata River Basin, Argentina and the estuarine system of Patos Lagoon, south Brazil. The presence of OMZ is an important factor in the separation into two groups off the Chilean coast $\left(\sim 39^{\circ} \mathrm{S}\right)$. The characterization of the oceanographic conditions showed that the northern boundary of the distribution of $P$. spinipinnis for the Pacific coast at Paita $\left(5^{\circ} \mathrm{S}\right)$ is coincident with the westward turn of the Humboldt Current, as it is incorporated into the South Equatorial Current. Off the Atlantic coast, the northern boundary seems associated with the Atlantic Subtropical Convergence $\left(30-40^{\circ} \mathrm{S}\right)$. The high temperatures $\left(>24^{\circ} \mathrm{C}\right)$ and salinities (>36psu) registered at the surface and at $50 \mathrm{~m}$ between the coasts and the $20 \mathrm{~nm}$ boundary were coincident with the known northern limit of the distribution of this species on both coasts of South America. In addition, we propose that Burmeister's porpoise presents a continuous distribution throughout this range from Paita, Peru to La Plata River Basin, Argentina, being able to reach Uruguayan and Brazilian waters under certain oceanographic conditions (e.g. intrusion of colder and less saline waters toward the north associated to the Subtropical Convergence).

\section{Acknowledgements}

This study was part of Doctoral Thesis of D. MolinaSchiller, which was supported by grants from Cetacean Society International, American Museum of Natural History, New York, the Society for Marine Mammalogy (Grant-in-Aid Program), and PPG-CAPES. We thank Dr. Dave Johnston and an anonymous referee for reviewing the English and for their helpful comments on the manuscript.

\section{References}

Ainley, D.G., Spear, L.B., Allen, S.G. And Ribic, C.A. (1995a) Temporal and spatial patterns in the diet of the common murre in Califorrnia waters. The Condor 98: 691-705.

Ainley, D.G., Sydeman, W.J. And Norton, J. (1995b) Upper trophic level predators indicate interannual negative and positive anomalies in the California Current food web. Marine Ecology Progress Series 118: 69-79.

Alheit, J. and Bernal, P. (1993) Effects of physical and biological changes on the biomass yield of the Humboldt Current Ecosystem. Pages 53-68 in Sherman, K., Alexander, L. M. and Gold, B. D. (Eds) Large Marine Ecosystems V: Stress, Mitigation and Sustainability. AAAS Press, Washington D.C.

AngeL, M.V. (1994) Long-term, large-scale patterns in marine pelagic systems. Pages 403-439 in Giller, P.S., Hildrew, A. G., Raffaelli, D.G. (Eds) Aquatic Ecology: Scale, Pattern, and Process. Blackwell Scientific Publications, Oxford, England. 
Anderson, J.J., Okubo, A., Robiins, S. And Richards, F.A. (1982) A model for nitrite and nitrate distributions in oceanic oxygen minimum zones. Deep-Sea Research 29: 1113-1140.

Arntz, W., Tarazona, J., Gallardo, V.A., Flores, L.A. and SAlzWEDEL, H. (1991) Benthos communities in oxygen deficient shelf and upper slope areas of Peruvian and Chilean Pacific coast, and changes caused by El Niño. Geological Society Special Publication 48: 131-154.

Aguayo, A.L. (1975) Progress report on small cetacean research in Chile. Journal of the Fisheries Research Board of Canada 32(7): 1123-1143.

BaKun, A., Csirke, J., Lluch-Belda, D. AND Steer-Ruiz, R. (1999) The Pacific Central American coastal LME. Pages 268-280 in TANG, Q. AND SHERMAn, K. (Eds) Large Marine Ecosystems of the Pacific Rim: Assessment, Sustainability and Management. Blackwell Science, Inc. Malden, MA.

BAumgartner, M.F. (1997) The distribution of Risso's dolphin (Grampus griseus) with respect to the physiography of the northern Gulf of Mexico. Marine Mammal Science 13: 614-638.

Baumgartner, M.F., Mullin, K.D., May, L.N. and Leming, T.D. (2001) Cetacean habitats in the northern Gulf of Mexico. Fishery Bulletin, US 99: 219-239

Benson, S.R., Croll, D.A., Marinovic, B.B., Chavez, F.P. and Harvey, J.T. (2002) Changes in the cetacean assemblage of a coastal upwelling ecosystem during El Niño 1997-98 and La Niña 1999. Progress in Oceanography 54: 279-291.

Blanco, J.L., Thomas, A.C., Carr, M.E. and Strub, P.T. (2001) Seasonal climatology of hydrographic conditions in the upwelling region off northern Chile. Journal of Geophysical Research 106(C6): 11451-11467.

BrownelL, R.L. AND Praderi, R. (1982) Status of Burmeister's porpoise, Phocoena spinipinnis, in South American waters. Mammals in the Seas. FAO Fisheries Series 5(4): 91 - 96.

Brownell, R.L. And Praderi, R. (1984) Phocoena spinipinnis. Mammalian Species 217: 1-5.

BROWNell R.L. AND ClaPHAM, P.J. (1999) Burmeister's porpoise - Phocoena spinipinnis Burmeister, 1865. Pages 393-410 in Ridgway S.H. and Harrison, S.R. (Eds) Handbook of Marine Mammals. Vol. 6. Academic Press, San Diego, CA.

BurMeISTER, H. (1865) Description of a new species of porpoise in the museum of Buenos Aires. Proceeding of the Zoological Society of London 1865: 228-231.

Campos, E.J.D, Velhote, D. and da Silveira, I.C.A. (2000) Shelf break upwelling driven by Brazil Current cyclonic meanders. Geophysical Research Letters 27(6): 751-754

Carretta, J.V., TAYlor, B.L. AND Chivers, S.J. (2001) Abundance and depth distribution of harbor porpoise (Phocena phocoena) in northern California determined from a 1995 ship survey. Fishery Bulletin US 99: 29-39.

Corcuera, J., Monzón, F., Aguilar, A., Borrell, A. and Raga, J.A. (1995) Life history data, organochlorine pollutants and parasites from eight Burmeister's porpoises, Phocoena spinipinnis, caught in northern Argentine waters. Pages 365372 in Bjørge, A. and Donovan, G. P. (Eds) Biology of the Phocoenids. Reports of the International Whaling Commission (special issue 16), Cambridge, England.

Dávila, P. M., Figueroa, D. and Müller, E. (2002) Freshwater input into the coastal ocean and its relation with the salinity distribution off austral Chile (35-55²). Continental Shelf Research 22: 521-534.

Davis, R.W., FARGiOn, G.S., MAY, N., LeMING, T.D., BAUMGartNer, M., Evans, W.E., Hansen, L.J. And Mullin, K. (1998) Physical habit of cetaceans along the continental slope in the north, central and western Gulf of Mexico. Marine Mammal Science 14: 490-507.

Deacon, G.E.R. (1933) The hydrology of Southern Ocean. Discovery Report 7: 171-238.

Donoso-Barros, R. (1975) Contribución al conocimiento de los cetáceos vivientes y fósiles del Territorio de Chile. Gayana 36:1-127.

Escribano, R., Fernández, M. And Aranis, A. (2003) Physicalchemical process and patterns of diversity of the Chilean eastern boundary pelagic and benthic marine ecosystem: an overview. Gayana 67(2): 190-205.

Fiedler, P.C., Methot, R.D. and Hewitt, R.P. (1986) Effects of California El Niño 1982-1984 on the northern anchovy. Journal of Marine Research 44: 317-338.

Forney, K.A. (2000) Environmental models of cetacean abundance: reducing uncertainty in population trends. Conservation Biology 14: 1271-1286.

Gallardo, V. A. (1963) Notas sobre la densidad de la fauna bentónica en el sublitoral del norte de Chile. Gayana 10: 3-15.

Garzoli, S.L. (1993) Geostrophic velocity and transport variability in the Brazil-Malvinas confluence. Deep-Sea Research 40: 1379-1403.

Goodall, R.N.P., Norris, K., Harris, G., Oporto, J. ANd Castello, H.P. (1995a) Notes on the biology of Burmeister's porpoise (Phocoena spinipinnis) off southern South America. Pages 317347 in BJørge, A. And Donovan, G.P. (Eds) Biology of the Phocoenids. Reports of the International Whaling Commission (special issue 16), Cambridge, England.

GoOdALL, R.N.P., WÜRSIG, B., WÜRSIG, M., HARRIS, G. AND NorRIS, K. (1995b) Sightings of Burmeister's porpoise, Phocoena spinipinnis, off southern South America. Pages 297-316 in BJørGE, A. AND Donovan, G.P. (Eds) Biology of the Phocoenids. Reports of the International Whaling Commission (special issue 16), Cambridge, England.

Gowans, S. AND WhiteHEAd, H. (1995) Distribution and habitat partitioning by small odontocetes in the Gully, a submarine canyon on the Scotian shelf. Canadian Journal of Zoology 73:1599-1608.

Guerra, C., Van Waerebeek, K., Portflitt, G. and Luna, G. (1987) The presence of cetaceans off the northern Chilean coast. Estudios Oceanológicos 6: 87-96.

Gutierrez, D., Gallardo, V.A., Mayor, S., Neira, C., Vásquez, C., Sellanes, J., Rivas, M., Soto, A., Carrasco, F. and Baltasar, M. (2000) Effects of dissolved oxygen and fresh organic matter on bioturbation potential of macrofauna in sublittoral sediments off Central Chile during the 1997/1998 El Niño. Marine Ecology Progress Series 202: 81-99.

Hastie, G.D., Swift, R.J., Slesser, G., Thompson, P.M. and TURRELL, W.R. (2005) Environmental models for predicting oceanic dolphin habitat in the Northeast Atlantic. Journal of Marine Science 62: 760-770.

HAMAZAKI, T. (2002) Spatiotemporal prediction models of cetacean habitats in the mid-western North Atlantic Ocean 
(from Cape Hatteras, North Carolina, U.S.A. to Nova Scotia, Canada). Marine Mammal Science 18: 920-939.

JeFFerson, T.A., LeATHERWOOD, S. AND WebBer, M.A. (1993) FAO Species Identification Guide. Marine Mammals of the World. Rome, FAO, 320 pp.

Jonhston, D.W., Westgate, A.J. AND ReAd, A.J. (2005) Effects of fine-scale oceanographic features on the distribution and movements of harbour porpoises Phocoena phocoena in the Bay of Fundy. Marine Ecology Progress Series 295: 279-293.

KAMYKOWSKI, D. AND ZentaRA, S.J. (1990) Hypoxia in the world ocean as recorded in the historical data set. Deep-Sea Research 37: 1861-1874.

Kenney, R.D., Winn, H.E. And Macaulay, M.C. (1995) Cetaceans in the Great South Channel, 1979-1989: right whale (Eubalaena glacialis). Continental Shelf Research 15: 385-414.

KLINOWSKA, M. (1991) Dolphins, Porpoises and Whales of the World. The IUCN Red Data Book. IUCN, Gland, Switzerland and Cambridge, England.

Lima, I.D., Garcia, C.A.E. And Möller, O.O. (1996) Ocean surface processes on the southern Brazilian shelf: characterization and seasonal variability. Continental Shelf Research 16: 1307-1317.

Littaye, A., Gannier, A., Laran, S. And Wilson, J.P.F. (2004) The relationship between summer aggregation of fin whales and satellite-derived environmental conditions in the northwestern Mediterranean Sea. Remote Sensing of Environment 90: 44-52.

LEGECKIS, R. AND GORDON, A. (1982) Satellite observations of the Brazil and Falkland Currents - 1975 to 1976 and 1978. DeepSea Research 29: 375-401.

Levin, L.A., Huggett, C.L. And Wishner, K.F. (1991) Control of deep-sea benthic community structure by oxygen and organic matter gradients in the eastern Pacific Ocean. Journal of Marine Research 49: 763-800.

Lusquiños, A.J. AND VaLdÉz, A.J. (1971) Aportes al conocimiento de las masas de agua del Atlántico Sudoccidental. Servicio de Hidrografía Naval, Buenos Aires, Argentina.

Mann, K.H. And Lazier, J.R.N. (1991) Dynamics of Marine Ecosystems. Blackwell Scientific Publications, Inc., Oxford, England.

Microimages (2001) Volume 3. Process. Reference Manual of TNTMips. 1065 pp.

Moore, S.E., DeMaster, D.P. And DAyton, P.K. (2000) Cetacean habitat selection in the Alaskan Arctic during summer and autumm. Arctic 53: 432-447.

Morales, C., Hormazabal, S.E. and Blanco, J.L. (1999) Interanual variability in the mesoscale distribution of the depth of the upper boundary of oxygen minimum layer off northern Chile (18-24S): implications for the pelagic system and biogeochemical cycling. Journal of Marine Research 57: 909-932.

NESHYba, S. AND FONSECA, T. (1980) Evidence for counterflow to the west wind drift off South America. Journal of Geophysical Research 82: 4888-4892.

OpORTO, J.A. AND BRIEVA, L. (1994) Interacción entre la pesquería artesanal y pequeños cetáceos en la localidad de Queule (IX Región), Chile. Pages 187-205 in Anales IV Reunión de Trabajo de Especialistas en Mamíferos Acuáticos de América del Sur, 12-15 November, 1990. Valdivia, Chile.
Olson, D.D., Podesta, G.P., Evans, R.H. and Brown, O.B. (1988) Temporal variations in the separation of Brazil and Malvinas Currents. Deep-Sea Research 35(12): 1971-1990.

Panella, S., Michelato, A., Perdicaro, R. Magazzu, G. Decembrini, F. and Scarazzato, P. (1991) A Preliminary contribution to understanding the hydrological characteristics of the Strait of Magellan; austral spring 1989. Bollettino di Oceanologia Teorica ed Applicata 9(2-3) (special issue): 107-126.

Peterson, R.G. and Stramma, L. (1990) Upper-level circulation in the South Atlantic Ocean. Progress in Oceanography 26: 1-73.

Piatkowski, U., Vergani, D.F. and Stanganelli, Z.B. (2002) Changes in the cephalopod diet of southern elephant seal females at King George Island, during El Niño-La Niña events. Journal of the Marine Biological Association of the United Kingdom 82: 913-916.

Pickard, G.L. (1973) Water structure in Chilean fjords. Pages 95-104 in Fraser, R. (Ed) Oceanography of South Pacific. 1973. New Zealand National Commission UNESCO, Wellington, New Zealand.

Pinedo, M.C. (1989) Primeiro registro de Phocoena spinipinnis (Cetacea, Phocoenidae) para o litoral do Rio Grande do Sul, Brasil, com medidas osteológicas e análise do conteúdo estomacal. Atlântica, Rio Grande 11(1): 85-99.

Pimenta, F.M. (2001) Estudo numérico da influência da descarga fluvial e dos ventos sobre a dinâmica da pluma do Rio da Prata. Master Thesis, Instituto Oceanográfico da Universidade de São Paulo, São Paulo, SP, Brazil. 127pp.

Piola, A.R., Campos, E.J.D., Möller JR., O.O., Charo, M. and Martinez, C. (2000) Subtropical shelf front off eastern South America. Journal of Geophysical Research 105 (C3): 6565-6578.

Podesta, G.P., Brown, O.B. And Evans, R.H. (1991) The annual cycle of satellite derived sea surface temperatures in the Southwestern Atlantic Ocean. Journal of Climate 4(4): 457-467.

Pyle, P., Klimley, A.P., Anderson, S.D. and Henderson, R.P. (1996) Environmental factors affecting the occurrence and behaviour of the white sharks at the Farallon Islands, California. Pages 281.291 in Klimley, A.P. AND Ainley, D.G. (Eds) Great White Sharks: the Biology of Carcharodon carcharias. Academic Press, San Diego, CA.

Rivas, A.L. AND Piola, A.R. (2002) Vertical stratification at the shelf off northern Patagonia. Continental Shelf Research 22: 1549-1558.

Reeves, R.R., Smith, B.D., Crespo, E.A. and Notarbartolo di Sciara, G. (compilers). (2003). Dolphins, Whales and Porpoises: 2002-2010 Conservation Action Plan for the World's Cetaceans. IUCN/SSC Cetacean Specialist Group. IUCN, Gland, Switzerland and Cambridge, England.

Reyes, J.C. And Oporto, J.A. (1994) Gillnet fisheries and cetaceans in the southeast Pacific. Report of the International Whaling Commission (special issue 15): 467-474. Cambridge, England.

Reyes, J.C. and VAn Waerebeeck, K. (1995) Aspects of the biology of Burmeister's porpoise from Peru. Pages 349-364 in Biology of the Phocoenids. BJørGe, A. And Donovan, G.P. (Eds), Reports of the International Whaling Commission (special issue 16), Cambridge, England.

Rosenberg, R, Arntz, W., Chumán de Flores, E., Flores, L.A., Carvajal, G., Finger, I. and Tarazona, J. (1983) Benthos biomass and oxygen deficiency in the Peruvian upwelling system. Journal of Marine Research 41: 263-279. 
Ross, G.J., Cосксroft, V.G. And Butterworth, D.S. (1987) Offshore distribution of bottlenose dolphins in Natal coastal waters and Algoa Bay, Eastern Cape. South African Journal of Zoology 22: 50-56

Sabatini, M., Reta, R. and Mantano, R. (2004) Circulation and zooplankton biomass distribution over the southern Patagonian shelf during late summer. Continental Shelf Research 24: 1359-1373.

Selzer, L.A. AND Payne, P.M. (1988) The distribution of whitesided (Lagenorhynchus acutus) and common dolphins (Delphinus delphis) vs. environmental features of the continental shelf of the northeastern Unites States. Marine Mammals Science 4: 141-153.

Schlitzer, R. (2004) Ocean Data View, http://www.awibremerhaven.de/GEO/ODV.

Sievers, H.A. AND Nowlin JR., W.D. (1989) Upper ocean characteristic in Drake Passage and adjoint areas of Southern Ocean, $39^{\circ} \mathrm{W}-95^{\circ} \mathrm{W}$. Pages 57-80 in SAHrHage, D. (Ed) Antarctic Ocean Resource Variability, Springer-Verlag, Berlin. Germany.

Silva, N. And Neshyba, S. (1979) Masas de agua y circulación geostrófica frente a la costa de Chile Austral. Serie Científica del Instituto Antártico Chileno 25/26: 5-32.

Silva, N., Calvete, C. and Sievers, H.A. (1997) Características oceanográficas físicas y químicas de canales australes chilenos entre Puerto Montt y Laguna San Rafael (Crucero CimarFiordo 1). Ciencia y Tecnología del Mar 20: 23-106.

Silva, L.C.F C., De Albuquerque, C.A.M., de Cavalheiro, W.W. AND Hansen, C.M.P. (1984) Gabarito tentativo para as massas de água da costa sudeste brasileira. Separata dos Anais Hidrográficos 51: 261-289.

Smith, R.C., Dustan, P., Au, D., Baker, K.S. and Dunlap, E.A. (1986) Distributions of cetaceans and sea surface chlorophyll concentrations in the California Current. Marine Biology 91: $385-402$

Simões-Lopez, P. And XIMÉnez, A. (1989) Phocoena spinipinnis Burmeister, 1865, na costa sul do Brasil (Cetacea-Phocoenidae). Biotemas 2(1): 83-89.

Stramma, L., Ikeda, Y. And Peterson, R.G. (1990) Geostrophic transport in the Brazil Current region north of $20^{\circ} \mathrm{S}$. Deep-Sea Research 37(12): 1875-1886.

Strub, P., Mesias, J., Montecino, V., Rutland, J., and Salinas, S. (1998) Coastal ocean circulation off western South America. Pages 271-313 in Robinson, A. And BRINK, K. (Eds) The Sea, Vol.11. The Global Coastal Ocean. First Workshop on Coastal Ocean Advanced Science and Technology Studies
(COASTS) IOC, Liege. John Wiley \& Sons, Inc., Somerset, NJ.

Sydeman, W.J. And Allen, S.G. (1999) Pinniped population dynamics in central California: correlations with sea surface temperature and upwelling indices. Marine Mammal Science 15: 446-461.

Tarazona, J. And Arntz, W. (2001) The Peruvian coastal upwelling system. Pages 229-244 in Seeliger, U. AND KJerfve, B. (Eds) Coastal Marine Ecosystems of Latin America. Ecological Studies, Vol. 144. Springer-Verlag, Berlin, Germany.

Torres, P., Oporto, J.A., Brieva, L.M. ANd Escare, L. (1992) Gastrointestinal helminthes of the cetaceans Phocoena spinipinnis (Burmeister, 1865) and Cephalorhynchus eutropia (Gray, 1846) from the southern coast of Chile. Journal of Wildlife Diseases 28(2): 313-315.

TRUKHIN, A.M. (2003) Oceanographic and biological conditions affecting the winter distribution of the spotted seal (Phoca largha) in the Sea of Okhotsk. Oceanology 43(3): 387-394.

Tynan, C.T., Ainley, D.G., Barth, J.A., Cowles, T.J., Pierce, S.D. AND SPEAR, L.B. (2005) Cetacean distribution relative to ocean processes in the northern California Current System. Deep-Sea Research II 52: 145-167.

Van Waerebeek, K., Santillán, L. and Reyes, J.C. (2002) An unusually large aggregation of Burmeister's porpoise Phocoena spinipinnis off Peru, with a review of sightings from the eastern South Pacific. Noticiario Mensual, Museo Nacional de Historia Natural 350:12-17.

Vivier, F. AND Provost, C. (1999) Direct velocity measurements in the Malvinas Currents. Journal of Geophysical Research 104: 21083-21103.

WALSH, J.J. (1991) Importance of continental margins in the marine biogeochemical cycling of carbon and nitrogen. Nature 350: 53-55.

Wisher, K.F., AshiIAN, C.J., Gelgman, C., Gowing, M., KanN, L., Levin, L.A., Mullineaux, L.S. and Saltzman, J. (1995) Pelagic and benthic ecology of lower interface of Eastern Tropical Pacific oxygen minimum zone. Deep Sea Research I (42): 93-115.

WÜrsig, M., WÜrsig, B. And Mermoz, J.F. (1977) Desplazamientos, comportamiento general y un varamiento de la marsopa espinosa, Phocoena spinipinnis, en el Golfo San José (Chubut, Argentina). Physis (Buenos Aires) 36(92): 71-79.

WÜRSIG, B. AND WÜRSIG, M. (1980) Behavior and ecology of the dusky dolphin, Lagenorhynchus obscurus, in the South Atlantic. Fishery Bulletin 77: 399-412. 